\title{
High-amplitude lake-level changes in tectonically active Lake Issyk-Kul (Kyrgyzstan) revealed by high-resolution seismic reflection data
}

\author{
Andrea Catalina Gebhardt ${ }^{1}$, Lieven Naudts ${ }^{2,3}$, Lies De Mol $^{3}$, Jan Klerkx ${ }^{4}$, Kanatbek Abdrakhmatov ${ }^{5}$, \\ Edward R. Sobel ${ }^{6}$, and Marc De Batist ${ }^{3}$ \\ ${ }^{1}$ Alfred Wegener Institute, Helmholtz Centre for Polar and Marine Research, 27576 Bremerhaven, Germany \\ ${ }^{2}$ Royal Belgian Institute of Natural Sciences, Operational Directorate Natural Environment (RBINS-OD Nature), \\ 8400 Ostend, Belgium \\ ${ }^{3}$ Renard Centre of Marine Geology, Universiteit Gent, 9000 Ghent, Belgium \\ ${ }^{4}$ International Bureau for Environmental Studies (IBES), 1090 Brussels, Belgium \\ ${ }^{5}$ Kyrgyz Institute of Seismology, Bishkek, Kyrgyzstan \\ ${ }^{6}$ Institut für Erd- und Umweltwissenschaften, International Universität Potsdam, 14476 Potsdam, Germany \\ Correspondence to: Andrea Catalina Gebhardt (catalina.gebhardt@awi.de)
}

Received: 7 January 2016 - Published in Clim. Past Discuss.: 18 January 2016

Revised: 14 November 2016 - Accepted: 21 November 2016 - Published: 18 January 2017

\begin{abstract}
A total of 84 seismic profiles, mainly from the western and eastern deltas of Lake Issyk-Kul, were used to identify lake-level changes. Seven stratigraphic sequences were reconstructed, each containing a series of delta lobes that were formed during former lake-level stillstands or during slow lake-level increase or decrease. The lake level has experienced at least four cycles of stepwise rise and fall of $400 \mathrm{~m}$ or more. These fluctuations were mainly caused by past changes in the atmospheric circulation pattern. During periods of low lake levels, the Siberian High was likely to be strong, bringing dry air masses from the Mongolian steppe blocking the midlatitude Westerlies. During periods of high lake levels, the Siberian High must have been weaker or displaced, and the midlatitude Westerlies could bring moister air masses from the Mediterranean and North Atlantic regions.
\end{abstract}

\section{Introduction}

In the marine environment, global eustatic sea-level curves are traditionally used to reconstruct the amount of water stored on continents and in the oceans (e.g., Haq et al., 1987; Fleming et al., 1998; Lambeck et al., 2014; Dutton et al., 2015). Sea level is a good measure for the volume of water stored as ice for shorter time periods during which other fac- tors such as tectonic subsidence, seafloor spreading, and thermal expansion can be ignored. Hence, sea-level curves can be used to reconstruct glacial/interglacial cycles on a global scale. During the Last Glacial Maximum, for example, the eustatic sea level was some 125 to $135 \mathrm{~m}$ lower than today (e.g., Fleming et al., 1998; Lambeck et al., 2014).

Lake-level curves, in contrast, often store a more local signal that might or might not be controlled by glacial/interglacial cycles. Many lakes with large water bodies and volumes of sediment infill are fed by extensive catchments, and hence provide a powerful tool for understanding paleoenvironmental and paleoclimate change not only on local but also on regional scale. Changes in lake level can be in the order of some meters, but can also be much larger than those recorded in the marine environment. Large-scale lakelevel changes of up to several hundreds of meters were observed in a series of large lakes, such as Lake Tanganyika (Lezzar et al., 1996), Lake Malawi (Scholz, 2007; Lyons et al., 2015), Lake Van (Cukur et al., 2014), Lake Lisan (Machlus et al., 2000), Lake Petén Itzá (Anselmetti et al., 2006), Laguna Potrok Aike (Anselmetti et al., 2009; Gebhardt et al., 2012), Lake Bosumtwi (Scholz et al., 2002), and Lake Chala (Moernaut et al., 2010). Lake Van (eastern Anatolia) is a large lake basin (Degens et al., 1984; Litt et al., 2009). During the past $600 \mathrm{ka}$, i.e., since its formation, its water 


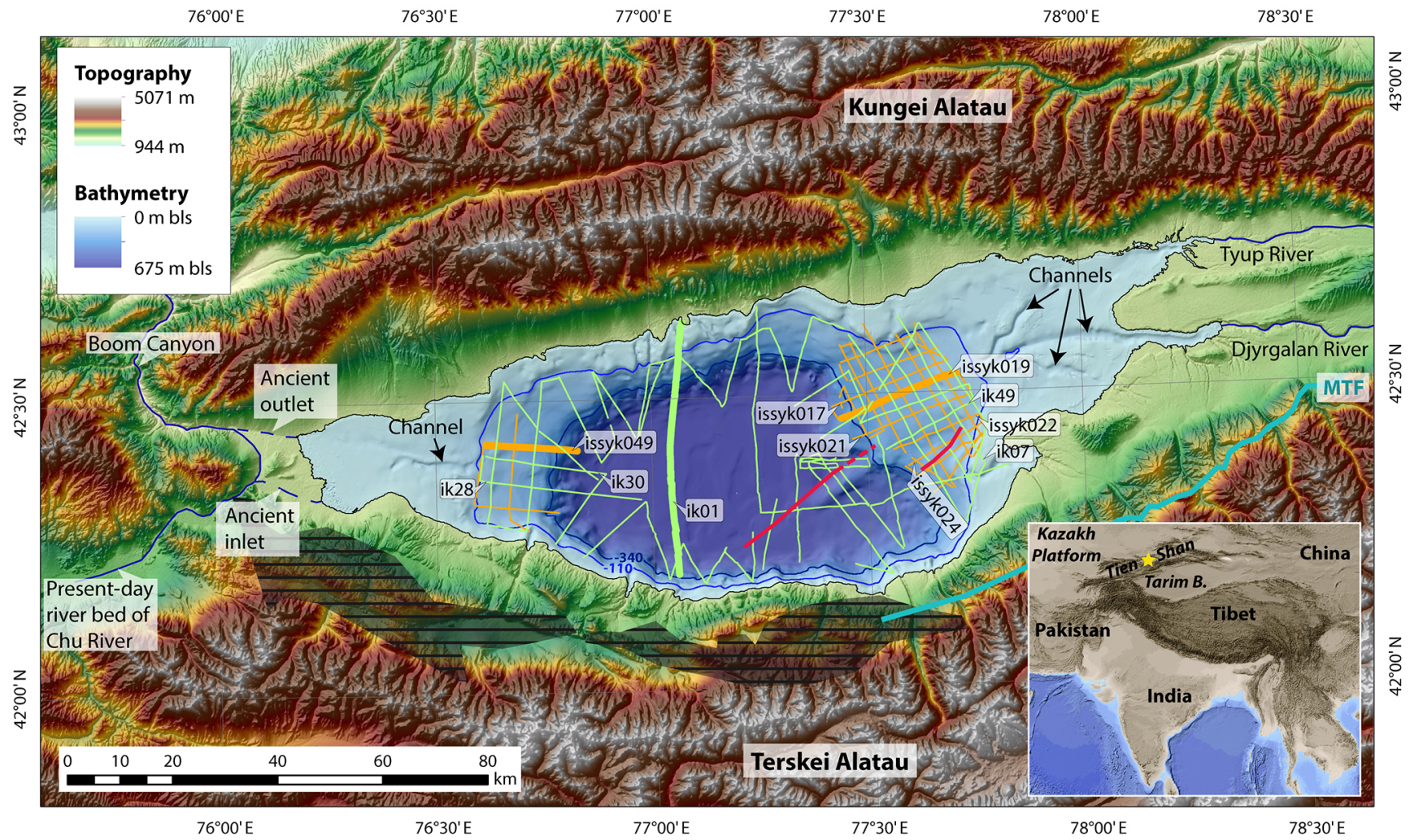

Figure 1. Geographical setting of Lake Issyk-Kul. Track lines of all profiles used in this study are shown in green (data from 1997) and orange (2001). Profiles shown in Figs. 3-6 and 8 are shown by bold lines. The axes of two anticline structures visible in the seismic profiles in the southeastern part of the lake are marked in red. Grey hatched areas mark the approximate position of the Issyk-Kul broken foreland. Blue line shows the approximate location of the main Terskey Fault (MTF; after Macaulay et al., 2014). Digital terrain model for the lake and surroundings from Delvaux et al. (2001). Bathymetry is given in meters below lake surface (m bls). Inset shows the location of our study site marked by a yellow star (map generated using the ETOPO1 dataset, Amante and Eakins (2009), projection: WGS84 UTM Zone 43N).

level changed by as much as $600 \mathrm{~m}$ (Cukur et al., 2014). While climate forcing was identified as the dominant factor in driving lake-level changes in Lake Van, other factors such as volcanic and tectonic forcing could also be observed (Cukur et al., 2014; Stockhecke et al., 2014). Lake Petén Itzá is located in the lowland Neotropics of northern Guatemala on the Yucatán Peninsula. A paleoshoreline was identified at $56 \mathrm{~m}$ below present lake level, which means a reduction of ca. $87 \%$ of the total water volume at that time (Anselmetti et al., 2006). Lake-level changes in Lake Petén Itzá were correlated to wet-dry paleoclimate patterns with lowstands during the stadials and highstands during the interstadial periods (Hodell et al., 2008). In Laguna Potrok Aike, a maar lake located in Patagonia, lake-level variations of up to $200 \mathrm{~m}$ during the past ca. $50 \mathrm{ka}$ point to latitudinal shifts in the Southern Hemisphere Westerlies and hence difference in moisture availability (Anselmetti et al., 2009; Gebhardt et al., 2012). Lake Lisan, the late Pleistocene precursor of the Dead Sea, is located in the Levant. The ancient lake is not filled with water anymore, but its sediments crop out at several locations around the Dead Sea. Lake Lisan existed between $\sim 70$ and $17 \mathrm{ka}$ when it started to recede to the presentday Dead Sea lake level (Schramm et al., 2000). Lake-level changes as large as $170 \mathrm{~m}$ (Bartov et al., 2002) have on the one hand been attributed to paleoclimate change, but on the other hand, basin morphology and barriers between subbasins are able to modify and restrict lake-level changes in this area (Bartov et al., 2002, and references therein). The impact crater of Lake Bosumtwi (Ghana, West Africa) is rather small with a diameter of $\sim 8 \mathrm{~km}$ (Scholz et al., 2002). This lake is hydrologically closed (Shanahan et al., 2006). Lake level in Lake Bosumtwi, therefore, is purely driven by evaporation / precipitation ratio, and the lake is therefore sensitive to changes in regional (and global) climate.

Lake Issyk-Kul (Kyrgyzstan, Central Asia), the subject of this study, is a large lake in a tectonically active region surrounded by the Tien Shan. It is comparable in size with other large lakes worldwide, and thus likely to archive changes of the atmospheric circulation as well as indications of tectonic changes affecting the lake's drainage basin in its sediments. We use high-resolution sparker seismic data to reconstruct past water-level changes in Lake Issyk-Kul. Possible mech- 
anisms are discussed that led to lake-level changes of up to $400 \mathrm{~m}$. Additionally, the potential of the lake to help unravel regional paleoclimate change is shown.

\section{Study area}

\subsection{Lake settings}

Lake Issyk-Kul is an endorheic lake located in an intermontane basin in the northern part of the Tien Shan in Kyrgyzstan, Central Asia $\left(42^{\circ} 30^{\prime} \mathrm{N}\right.$ and $77^{\circ} 10^{\prime} \mathrm{E}, 1607 \mathrm{~m}$ altitude) between the relatively rigid Tarim Basin to the south and the Kazakh Platform to the north. The lake is bordered by the high mountains of the Terskei Alatau range to the south (max. height $5212 \mathrm{~m}$ ) and the Kungei Alatau range to the north (max. height $4771 \mathrm{~m}$; Fig. 1). The lake is elongated: $\sim 180 \mathrm{~km} \mathrm{E-W}$ and $\sim 60 \mathrm{~km} \mathrm{~S}-\mathrm{N}$. With a surface area of $6232 \mathrm{~km}^{2}$, Lake Issyk-Kul is the second largest lake at higher altitudes (De Batist et al., 2002). It has a mean water depth of ca. $278 \mathrm{~m}$ and an approximate water volume of 1736 km³ $^{3}$ (Korotaev, 1967; Kodyaev, 1973; Zabirov, 1978).

The lake has a deep central basin with a flat bottom $(668 \mathrm{~m}$ water depth) that extends over approximately $25 \%$ of the present lake area (Fig. 1). Two large-scale shallow platforms characterize the lake at its western and eastern end, with the deltaic area being as wide as $60 \mathrm{~km}$ in the eastern and $40 \mathrm{~km}$ in the western part. Shelf areas in the north and south of the lake are rather narrow and separated from the central lake basin by steep slopes. At the delta areas, the shelf is divided into two parts, one shallower part with water depths down to $110 \mathrm{~m}$ with an average inclination of $0.5^{\circ}$, and the other with water depths between 110 and $340 \mathrm{~m}$ and an average inclination of $1^{\circ}$ (De Mol, 2006). Incised channels of up to $2-3 \mathrm{~km}$ width and $50 \mathrm{~m}$ depth are visible on both the eastern and the western shelf (Fig. 1), but are limited to the shallower part of the shelf. They are found in the prolongation of modern river mouths at the eastern part of the lake, and are quite likely connected to former in- and outlets of the Chu River at the western delta (De Mol, 2006). The deeper part of the shelf is characterized by a series of terraces that were interpreted as ancient delta lobes, indicating lower water levels (De Batist et al., 2002).

The lake is fed by a total of 118 rivers and creeks draining an area of $22080 \mathrm{~km}^{2}$. These rivers mainly carry meltwater from snow and glaciers, rain, and groundwater (Aizen et al., 1995). The largest rivers are the Djyrgalan and Tyup rivers that feed into Lake Issyk-Kul at its eastern end. At present, Lake Issyk-Kul has no outlet, but during its history it drained through the Chu River at its western end (De Batist et al., 2002). Approximately $640 \mathrm{~km}^{2}$ of the drainage area are currently covered by glaciers that are located at altitudes of at least $3000 \mathrm{~m}$ a.s.l. Most of these glaciers are found on the north flanks of the Terskei Alatau range. During the last glacial period, the glaciers extended down to the coast of Lake Issyk-Kul (Grosswald et al., 1994). It is unclear if the lake was ice-covered during glacials or if the glaciers extended onto the shelf.

Lake Issyk-Kul is oligothrophic to ultra-oligotrophic and well-oxygenated through the entire water column down to the lake bottom. Surface water temperature does not drop below $2-3{ }^{\circ} \mathrm{C}$ in the winter and reaches $19-20^{\circ} \mathrm{C}$ during the summer. The lake is located in an arid area with deserts in the west, followed by semi-deserts and steppe towards east (Merkel and Kulenbekov, 2012). Salinity of the lake water is currently approximately $6 \mathrm{mg} \mathrm{L}^{-1}$ (Merkel and Kulenbekov, 2012).

\subsection{Tectonic setting}

The Tien Shan are one of the most important intracontinental orogenetic regions in Central Asia. Uplift and exhumation of the crystalline basement with its Paleozoic sediment cover possibly started in the late Oligocene. This has happened as a consequence of the progressive convergence of India and Eurasia after their collision in the Eocene (e.g., Goryachev, 1959; Molnar and Tapponier, 1975; Trofimov, 1990; Abdrakhmatov et al., 2002). During the Cenozoic, several strike-slip faults were active in this area, resulting in a transpressional tectonic context (Vermeesch et al., 2004). Exhumation of the Terskei Alatau and deposition of the basin fill began in the late Oligocene (Macaulay et al., 2013, 2015; Wack et al., 2014). GPS measurements show that the Tarim Basin moves towards the north with approximately 15 to $20 \mathrm{~mm}$ per year with respect to Eurasia. The area is tectonically, highly active as documented by recent and historic high-magnitude earthquakes (e.g. 1911: $M=8.2$ ) that often result in large subaerial landslides and quite likely also trigger large subaquatic mass movements. Most of the presentday tectonic activity is focused along the margins of the intermontane basins. Uplifted Pliocene lacustrine deposits are exposed at the southern shore of the lake. They are truncated by horizontal Quaternary lacustrine terraces, and some of the sediments were identified as deposited or deformed during earthquakes (Bowman et al., 2004). These subaerial lacustrine deposits could be exposed due to geodynamic activity in this area, but at the same time, they could also point to lake-level variations to higher lake levels than today. Hydrologically induced lake-level changes and uplift/subsidence are the two mechanisms that can form lake-level terraces at different heights. Hence, these two end members have to be considered for interpretation.

\section{Data acquisition and processing}

First seismic data of the Lake Issyk-Kul sedimentary infill and architecture were acquired in 1982 by the Moscow State University with a total of 31 profiles across the lake. Unfortunately, only a few profiles were ever published (Stavinsky et al., 1984). Additional seismic profiles were acquired in 1997 and 2001 (Fig. 1) by the Renard Centre of Ma- 


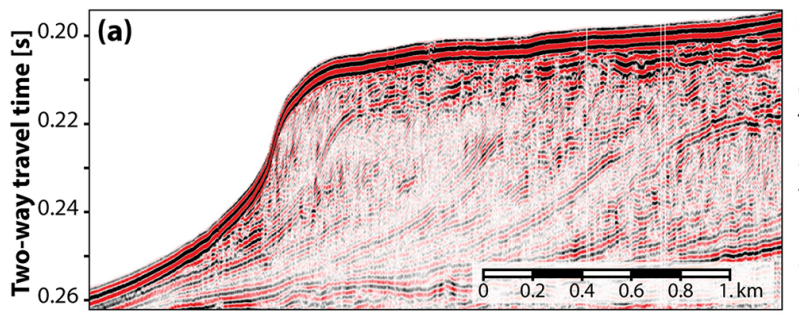

Seismic facies 1

Characteristics:

Topsets and bottomsets with high to moderate amplitudes and parallel to subparallel reflections; foresets with moderate to low amplitudes, moderate-continuity reflections, sinusoidal outer shape

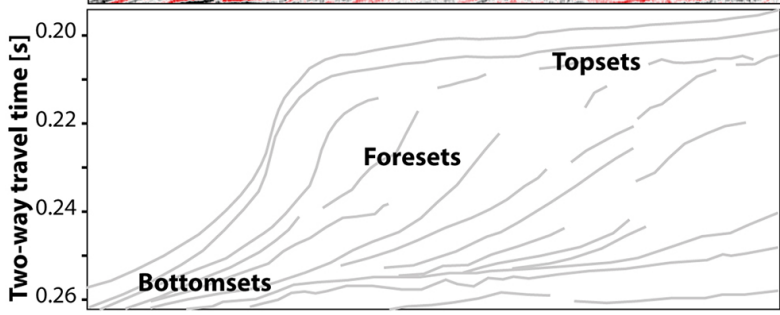

\section{Geological interpretation:}

Prograding delta lobes with characteristic lateral and/or vertical succession of topsets, foresets, and bottomsets.

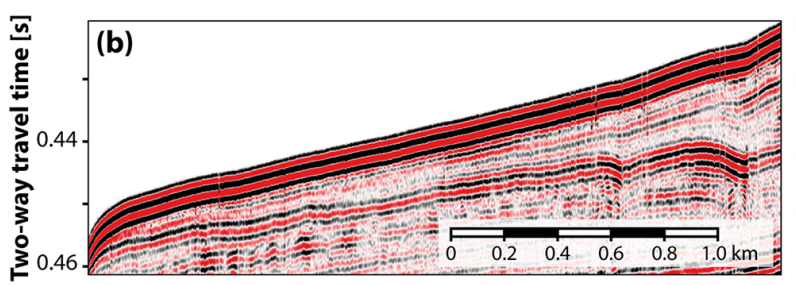

Seismic facies 2

Characteristics:

High to moderate amplitudes and parallel to subparallel reflections; high-continuity reflections

Geological interpretation:

Prodelta sediments

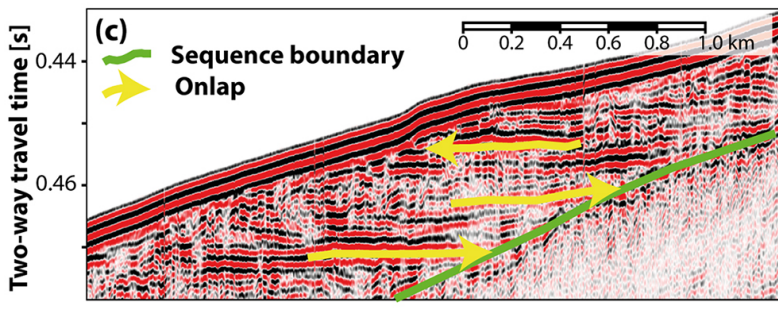

Seismic facies 3

Characteristics:

High to moderate amplitudes and parallel to subparallel reflections; moderate-continuity reflections that form onlaps to both sides. Superjacent reflections are located closer to the shoreline.

Geological interpretation:

Transgressional delta sediments/back-stepping delta

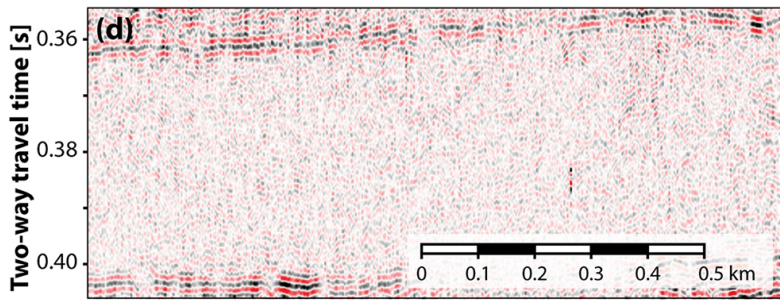

Seismic facies 4

Characteristics:

Variable but mostly low amplitude, acoustically transparent

\section{Geological interpretation:}

Delta sediments that were affected by post-depositional processes such as sediment remobilization or liquefaction that destroyed the internal structures

Figure 2. Seismic facies types, SF1-4, of Lake Issyk-Kul sediments. All examples were taken from profile issyk019 (for location of the profile refer to Fig. 1).

rine Geology (RCMG, Ghent University, Belgium). In 1997, 62 profiles $(\sim 990 \mathrm{~km})$ were collected using a Centipede multi-electrode sparker $(150-1500 \mathrm{~Hz}$, operated at $500 \mathrm{~J})$ as acoustic source (Imbo, 1998). In 2001, 40 additional profiles $(\sim 600 \mathrm{~km})$ were acquired with the same source, and another 12 profiles using a SIG sparker $(200-800 \mathrm{~Hz}$, operated at $500 \mathrm{~J}$ ). During both surveys, a single-channel streamer ( $2.7 \mathrm{~m}$ length, 10 hydrophones at $0.3 \mathrm{~m}$ spacing) was used as seismic receiver (Naudts, 2002). Recording time and shot interval were chosen depending on the water depth of the specific area. The incoming signal was bandpass-filtered be- tween 100 and $3000 \mathrm{~Hz}$ and subsequently digitized using a Triton-Elics DELPH2 data acquisition system with a sampling frequency of $5 \mathrm{kHz}$. Data were later converted to standard SEG-Y format for further processing. Navigation was recorded using a Simrad Shipmate GPS system. Seismic processing comprised filtering, deconvolution, migration, and amplitude scaling.

For the interpretation of the seismic database, all profiles were imported into Kingdom Suite. Prominent sequence boundaries, both erosive and nonerosive, were mapped throughout all profiles except where either the sequences 
were not imaged due to the geographical location of the profiles or due to limits in acoustic penetration/masking by the multiple. Even though sequence boundaries could not be mapped continuously between the eastern and western stacked-delta complexes, it was still possible to identify the same sequences in both areas due to similar two-way travel time depths of the individual corresponding delta lobes. Twoway travel time was converted to depth below lake level (b.l.1.) using a sound velocity of $1500 \mathrm{~m} \mathrm{~s}^{-1}$. Thickness maps for sequence boundaries were generated using the "natural neighbor" tool of ArcGIS with a cell size of $500 \mathrm{~m}$. Around the seismic profiles, a buffer of $500 \mathrm{~m}$ was calculated and used to mask the grid.

\section{Results and interpretation}

\subsection{Seismic facies analysis}

The seismic profiles of Lake Issyk-Kul are characterized by a variety of acoustic facies. While the central part of the lake is characterized by inclined strata that were deposited in a layer-cake manner, the slope and shelf are much more diverse in their acoustic image. Here, we concentrate on the eastern and western slope and shelf areas where we identified four different seismic facies types, SF1-4 (Fig. 2). These can be described as follows.

\subsubsection{Seismic facies 1 (SF1)}

This facies type is characterized by parallel to subparallel reflections with high to moderate amplitudes (Fig. 2a). Amplitudes are generally lower in the deeper sequences, which is rather the result of limited acoustic penetration than a real signal. In between the parallel to subparallel reflections a succession of prograding sequences with sinusoidal outer shape are observed (Fig. 2a). These are characterized by moderate to low amplitudes and moderate-continuity reflections. SF1 is found throughout almost all stratigraphic sequences both in the eastern and western delta area. The parallel to subparallel reflections can be interpreted as topsets and bottomsets of a delta, while the sinusoidal sequences are the corresponding foresets. SF1 is hence interpreted as prograding delta lobes with the characteristic lateral and/or vertical succession of topsets, foresets, and bottomsets. The sediments likely consist of coarse-grained material brought into the lake by the large rivers such as the Tyup and Djyrgalan rivers in the eastern and the Chu River in the western delta.

\subsubsection{Seismic facies 2 (SF2)}

This facies type is characterized by parallel to subparallel reflections of high to moderate amplitudes that can be followed over distances of several kilometers (Fig. 2b). The reflections form a drape or onlap onto the underlying reflections, and they are mostly found in locations distal to SF1. This facies is interpreted as distal deltaic sediments, i.e., prodelta sediments, and likely consist of fine-grained material brought by the rivers, possibly intercalated with turbidites.

\subsubsection{Seismic facies $3(\mathrm{SF} 3)$}

This facies type is characterized by a series of parallel to subparallel reflections with high to moderate amplitudes (Fig. 2c), similar to the topset part of SF1. The reflections form onlaps onto the underlying sequence boundary/reflections as well as onto the overlying layers. Each superjacent reflection is located closer to the shoreline. This facies type is interpreted as transgressional deltaic sediments or back-stepping deltas during times of rapid lake-level rise.

\subsubsection{Seismic facies 4 (SF4)}

This facies type is mostly acoustically transparent with low amplitudes (Fig. 2d). Where amplitudes are high enough for reflections to be detected, they are chaotically distributed. This facies is mainly found in the deeper parts of the delta where it forms a thick package of sediments, laterally bounded by sediments of SF2 towards the more distal part of the delta. SF4 may be interpreted as former delta sediments that have been affected by post-depositional processes (e.g., sediment remobilization, slumping, liquefaction) that caused them to lose their internal structure, or they may just consist of coarse-grained sediments.

\subsection{Identification of stratigraphic sequences in the seismic profiles}

The seismic profiles across the eastern and western delta areas were interpreted in terms of stratigraphic sequences following the principles of Vail et al. (1977). Stratigraphic sequences are always determined by their upper and lower boundaries. Unconformities are easily recognized as surfaces onto which reflections converge. Erosion truncates older strata that hence form toplaps or onlaps onto the erosional discordance (Fig. 3). Also the occurrence of downlaps, i.e., strata that terminate onto an underlying stratigraphic boundary, is indicative for sequence boundaries. Once the boundary is identified, it can be traced along the entire profile even in areas where it becomes conformable (Fig. 3).

Boundaries between the different sequences in Lake Issyk$\mathrm{Kul}$ are often erosive, but in places they are also nonerosive, i.e., conformable. Erosive boundaries, i.e., erosional unconformities marked by truncation of underlying reflections and/or irregular morphology, point to a lake-level fall while nonerosive boundaries, i.e., conformities, were formed during times with stagnating or rising lake levels.

Seven stratigraphic sequences were identified. The sequences are imaged on almost all seismic profiles except where they were masked by the lake-floor multiple, where 

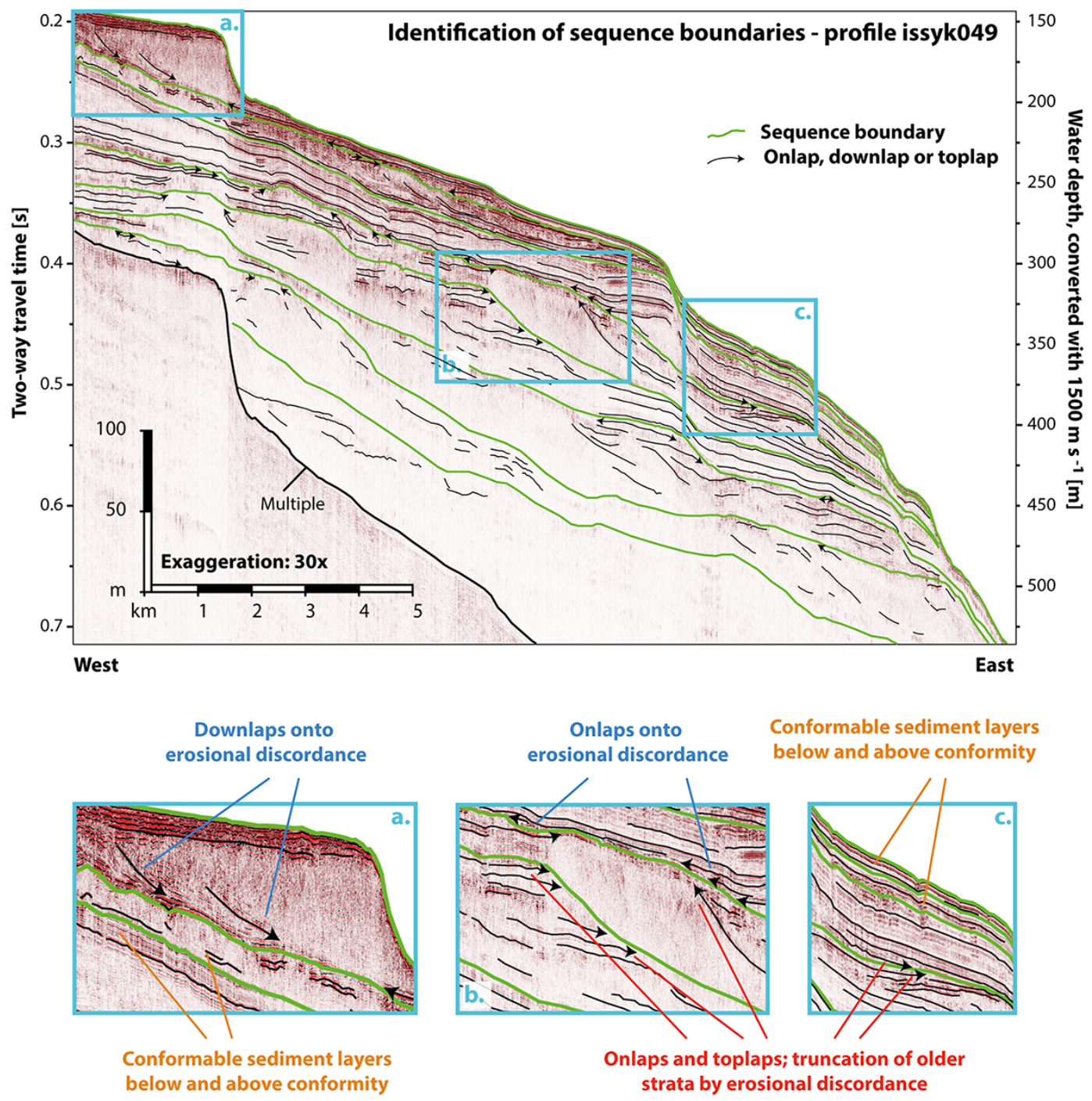

Figure 3. Identification of sequence boundaries of Lake Issyk-Kul sediments. Sequence boundaries could best be determined in places where underlying strata were truncated by erosion, and strata hence form onlaps or toplaps onto the erosional discordance. Also where overlying strata form downlaps or onlaps onto the stratigraphic boundary these were easily identified. Once identified, stratigraphic boundaries could also be traced as distinct reflections into places where they separate the upper and lower stratigraphic sequence as a conformity.

acoustic penetration was limited, or where the location of the profiles was not suited to image that specific sequence.

S3 and S4 were clearly identified in the western profiles, but could not be differentiated from each other on the profiles across the eastern delta area.

\subsection{Description of seismic profiles}

\subsubsection{Profile ik01}

Profile ik01 was acquired near the center of the lake and is aligned almost straight in north-south direction (Fig. 1). The profile shows well-layered sediments with a gentle dip towards south (Fig. 3). While the lake floor is not inclined, dip angle increases to roughly $15^{\circ}$ at $200 \mathrm{~m}$ sediment depth.
Small mass-transport deposits are intercalated with the welllayered sediments and are mainly found close to the slopes (Fig. 4).

\subsubsection{Profile issyk049}

Profile issyk049 is located in the western part of the lake (Fig. 1). It was acquired perpendicular to the shelf to best image the delta sequences below. The profile shows sedimentary layers that generally dip towards east, i.e., towards the lake center (Fig. 5). In profile issyk049, seven different stratigraphic sequences, S1 (youngest) to S7 (oldest), could be identified. Underneath the lowermost sequence, more lacustrine sediments are visible, but could not be interpreted due to poor acoustic penetration. The acoustic basement was 

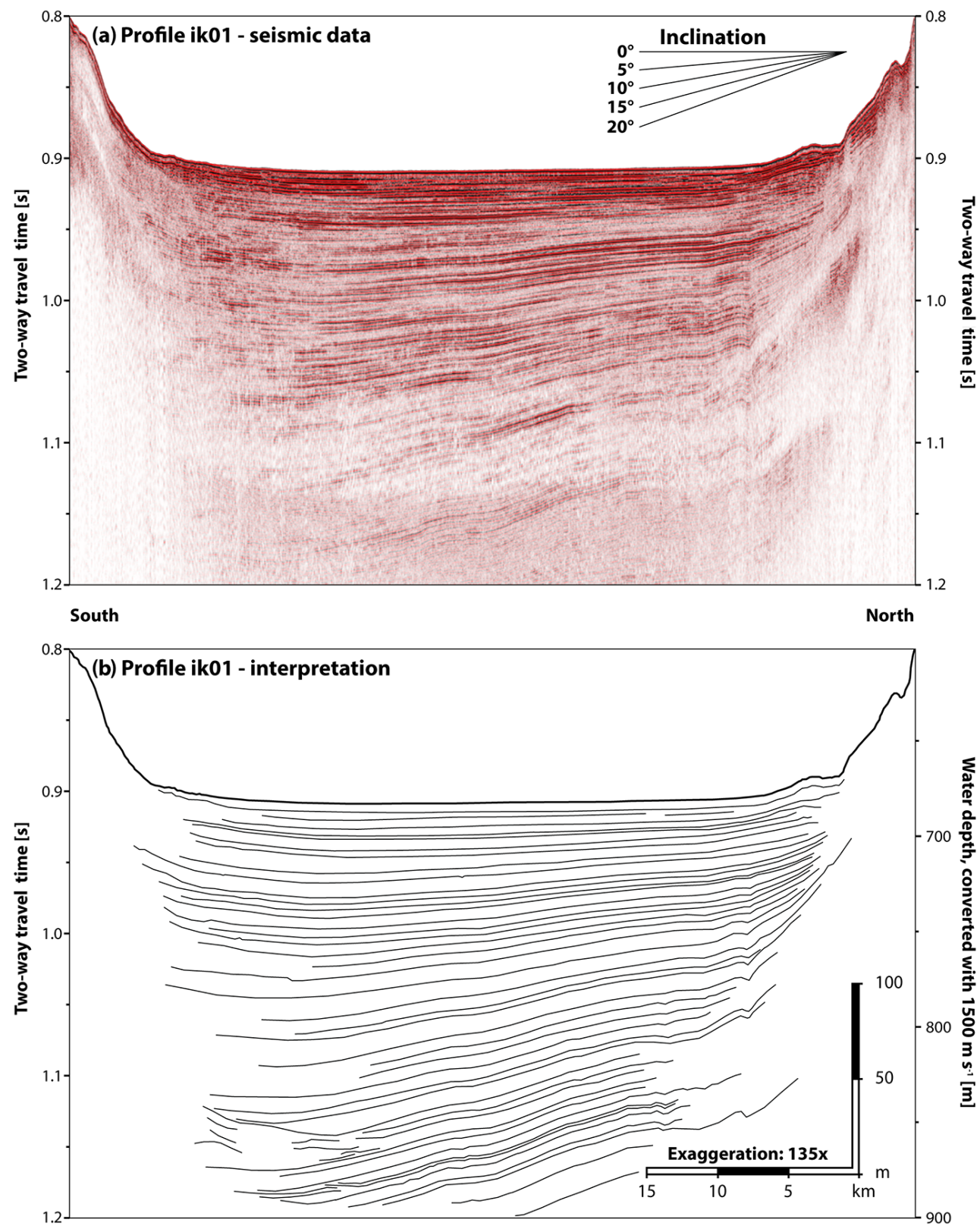

Figure 4. North-south profile ik01. The asymmetric nature of the lake basin is clearly visible with considerably higher subsidence rates towards south.

not detected in this profile. In each of the seven stratigraphic sequences several deltas could be identified (Fig. 5). In accordance with the other profiles of both the western and eastern area, these deltas could be numbered. Deltas were named $x . y$, where $x$ indicates the sequence in which it was detected and $y$ indicates the number of the delta within this sequence. $y$ starts with 1 for the first delta deposited in this sequence, and is consecutively incremented by 1 for each subsequent delta (Fig. 5). None of the profiles contained all of the delta lobes. For example, for S1 a total of 7 deltas were identified, while only $1.3,1.5$, and 1.6 were observed in profile issyk049. In some cases, deltas were missing because they were eroded after deposition. In other cases, they may not have been deposited at all, maybe due to varying input paths of the sediment. The current rivers on the eastern end and the Chu River on the western end of the lake may not always have had the same river bed; mainly during lake-level lowstands, they may have changed their pathway. Sediment supply hence may have limited the buildup of deltas. 

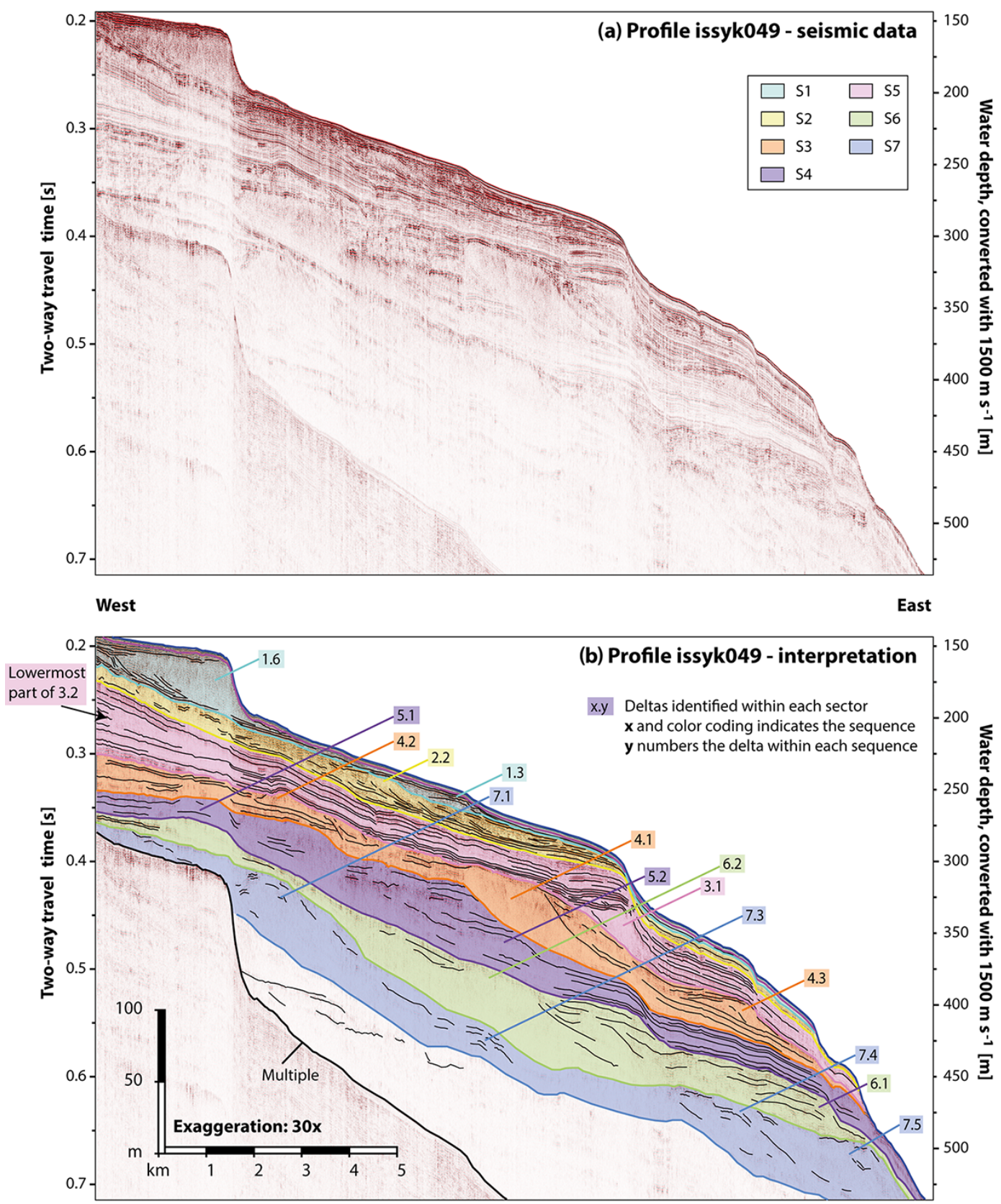

Figure 5. Seismic profile issyk049. Upper panel: seismic data. Lower panel: line drawing and interpretation of all sequences identified in the profile. All delta lobes identified in issyk049 are indicated. See Fig. 1 for location of profile issyk049.

\subsubsection{Profile issyk019}

Profile issyk019 is located in the eastern part of the lake (Fig. 1). Similar to issyk049, it was acquired perpendicular to the shelf to best image the delta sequences below, but it does not extend as far into the basin as the former. The profile shows sedimentary layers that generally dip towards west, i.e., towards the lake center (Fig. 6). In profile issyk019, only six different stratigraphic sequences could be identified, and in comparison with the other profiles of both east and west it became obvious that the sequence boundary between $\mathrm{S} 3$ and $\mathrm{S} 4$ could not be identified in the eastern area. S3 and S4 were hence treated as a combined sequence to stay consistent with the western area; referred to as "S3\&S4". Again, more lacustrine sediments were visible underneath the lowermost sequence but could not be interpreted. The acoustic basement was not detected in this profile either. In each of the six stratigraphic sequences except S3\&S4 several deltas could be identified and numbered accordingly to issyk0149 (Fig. 6). 

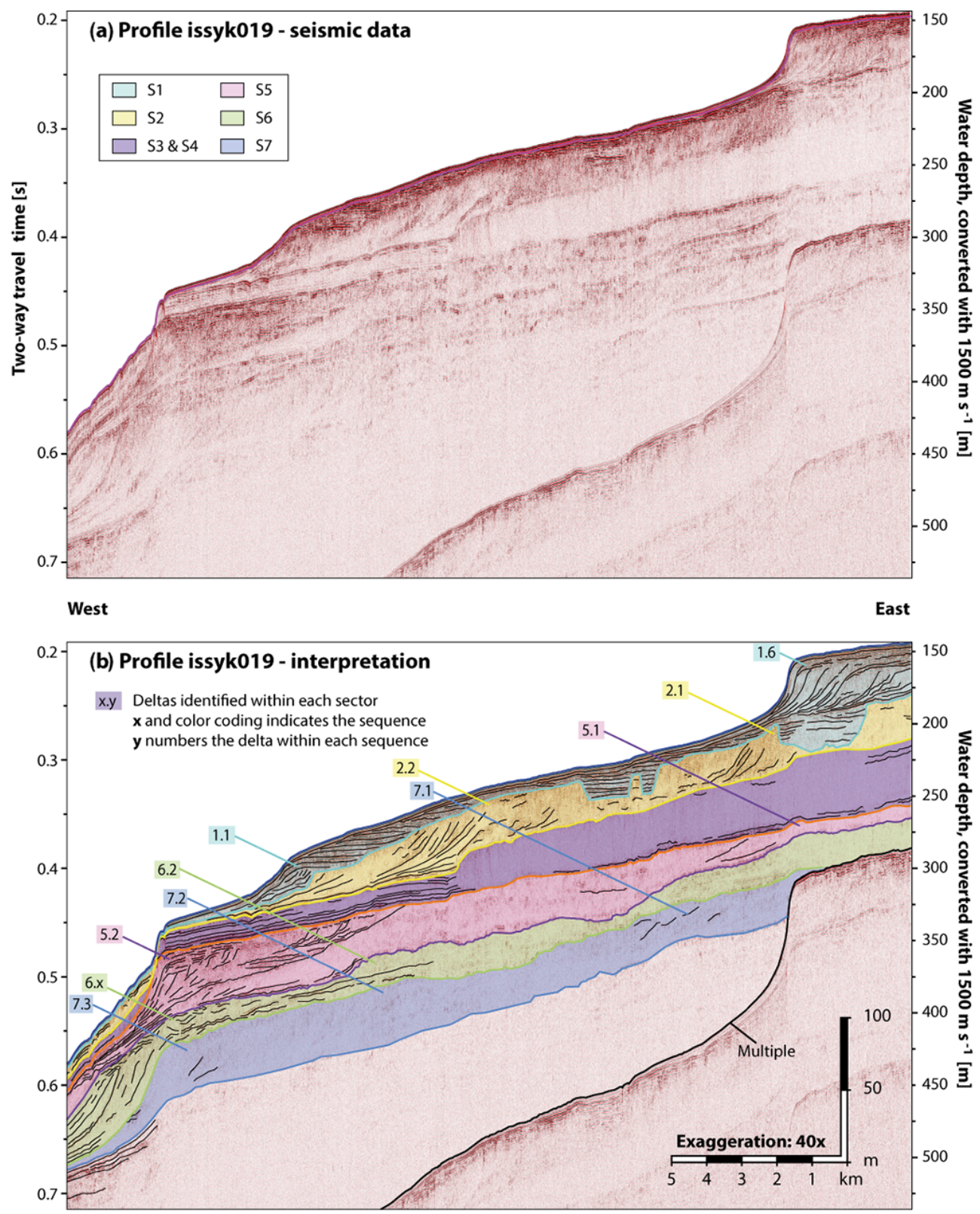

Figure 6. Seismic profile issyk019. Upper panel: seismic data. Lower panel: line drawing and interpretation of all sequences identified in the profile. All delta lobes identified in issyk019 are indicated. One delta lobe was spotted in S6 but could not be clearly identified because it is too eroded. This delta lobe is marked as $6 . x$ in the figure and was not considered for the reconstruction of the lake-level curve. See figure 1 for location of profile issyk019.

\subsection{Description and interpretation of stratigraphic sequences}

The sequences are described and interpreted in the following sections following the stratigraphic order, i.e., from the oldest sequence (S7) towards present (S1). We use delta depth (expressed in meters below current lake level, mb.l.1.) as an indicator for past lake-level change. The topset-foreset rollover point of the prograding clinoforms is considered as a proxy for the lake level at the time of its formation. The current topset-foreset rollover point is at $\sim 30 \mathrm{~m} \mathrm{~b}$.1.1., therefore, all delta depths were corrected by $-30 \mathrm{~m}$ for the lakelevel curve. No corrections were made for compaction and/or tectonic subsidence. Sediment thickness for S1-6 was calculated using a mean acoustic velocity of $1500 \mathrm{~m} \mathrm{~s}^{-1}$ for conversion between two-way travel time and depth. Sediment thickness, however, gives only a minimum estimate of the original thickness; even more if considering that acoustic velocities for coarser-grained sediments could be slightly higher than $1500 \mathrm{~m} \mathrm{~s}^{-1}$. Many parts of the sequences were 
eroded before the deposition of the overlying sequence, which is clearly visible by truncated strata and erosional discontinuities (Fig. 3). Furthermore, additional accommodation space for the overlying sequences was created by incision of rivers into older strata during lake-level lowstands.

S7 is the lowermost sequence that is visible in the seismic profiles (Figs. 5 and 6). Its lower boundary is masked in places by the multiple and/or limited penetration of the acoustic signal. Where its lower boundary is visible, it is clear that the seismic survey did not penetrate down to the acoustic basement, but that S7 is actually overlying sediments of unknown thickness. The upper boundary is defined by truncated strata within S7 and conformable sediment layers in S6 in the distal parts, and can be traced throughout the more proximal part of the profiles. Within S7, a series of five delta lobes could be identified, i.e., spatially well-defined parts of the sequence characterized by the SF1. Some of these occur only in the western delta area $(7.5,7.4)$, some only the eastern delta area (7.2), and some in both areas (7.3, 7.1). The stratigraphic succession of delta lobes 7.1 to 7.5 indicates a stepwise lake-level falls with stillstands at 330, 381, 412, 454, and $504 \mathrm{~m}$ b.1.1. (Table 1).

S6 is clearly visible both on the western and eastern delta areas. It overlies S7, is rather thin and forms downlaps onto the underlying and toplaps/onlaps onto the overlying erosional discontinuity in many profiles (Fig. 5). Two delta lobes could be identified at 461 (6.1) and $361 \mathrm{~m}$ b.1.1. (6.2; Table 1). S6 can thus be interpreted as deposited during lake-level rise with a first stillstand at 461 and a second stillstand at $361 \mathrm{~m}$ b.1.1. Sediment thickness of S6 increases with increasing water depth at least in the western delta area (Fig. 7).

S5 overlies S6 (Figs. 5 and 6). It is characterized by two deltas at $284 \mathrm{~m}$ b.1.1. (5.1) and $364 \mathrm{~m}$ b.1.1. (5.2; Table 1). The topographically higher delta 5.1 exhibits extensive erosion on the eastern delta (Fig. 6). The bathymetrically lower delta 5.2 is still visible in the modern lake floor morphology as it is only draped by the overlaying sequences; it forms the current shelf edge. S5 can be interpreted as having formed during a stepwise lake-level fall from a first stillstand at $284 \mathrm{~m}$ b.1.1. to a second stillstand at 364. It is quite likely that extensive erosion of the upper part of delta lobe 5.1 took place during the deposition of the lower lobe 5.2. Sediment thickness of S5 reveals two distinct depot centers in the western and one in the eastern delta area. Furthermore, sediment thickness could point to a paleo-river channel incised in S6 in the eastern delta area that is not located in the prolongation of one of the present large rivers (Tyup and Djyrgalan; see Fig. 1).

S4 overlies S5, and it is visible in both the western and eastern delta areas. On the latter, its upper boundary with
$\mathrm{S} 3$ is unclear due to the fact that S3 is not clearly visible in this area (Fig. 6). S4 in the eastern delta area either includes S3 and the boundary in between is not visible, or S3 is completely eroded here. Sediment thickness for the combined S3\&S4 in the eastern area shows increasingly thicker sediments towards the northern part of the delta, and a surprisingly thin thickness with little variance in the area south of $42^{\circ} 30^{\prime}$ (Fig. 7). It is likely that erosion was larger in this area, but the causes cannot be addressed with the current seismic database. In the western delta, in contrast, S4 is rather thick (Fig. 7) and its strata are truncated indicating an erosive discontinuity between S4 and S3 (Fig. 3). In S4, the delta lobes are characterized by predominantly acoustically transparent sediments of SF4, but the sequence also contains packages of well-layered prodeltaic sediments of SF2 (Fig. 5) in the distal parts of the different delta lobes. Three delta lobes were identified: the oldest (4.1) at ca. $319 \mathrm{~m}$ b.1.1., followed by a delta (4.2) at approximately $250 \mathrm{~m}$ b.1.1. and a third, younger (4.3), at $397 \mathrm{~m}$ b.1.1. (Table 1). S4 indicates a lake-level rise from a lower stillstand at $319 \mathrm{~m}$ b.1.1. to a second stillstand at 250 , followed by a subsequent lake-level fall with another stillstand at $397 \mathrm{~m}$ b.1.1.

S3 could only be clearly identified in the western delta areas (Figs. 5 and 6). In the western delta complex, S3 is characterized by a lower boundary that was partially erosive into the underlying sediments but grades into a correlative conformity in other places. Two distinct delta lobes were identified within S3, the older at 330 (3.1) and the younger at $172 \mathrm{mb}$ b.1.1. (3.2; Table 1). S3 can be interpreted as having formed during a lake-level rise with two stillstands, one at $330 \mathrm{~m}$ b.1.1., followed by a rapid lake-level rise and a second stillstand at $172 \mathrm{~m}$ b.1.1.

S2 is visible in almost all profiles in the eastern and western delta areas (Figs. 5 and 6). In the eastern delta area, due to the partial acoustic transparency of the underlying S3\&S4 it is not clear if the lower boundary of S2 is erosive or nonerosive; where S3\&S4 is not acoustically transparent but layered, the boundary between $\mathrm{S} 2$ and $\mathrm{S} 3$ seems to be nonerosive. In the western delta area, the lower boundary of S2 is clearly nonerosive. $\mathrm{S} 2$ is characterized by two delta lobes that were formed at 210 (2.1) and at $250 \mathrm{mb}$ b.1.1. (2.2; Table 1). S2 can be interpreted as a succession of stepwise, slow lakelevel fall with stillstands at 210 and later at $250 \mathrm{~m}$ b.1.1. During the lake-level fall, erosion may have taken place in the upper, proximal parts of the lake that were aerially exposed, but this is not visible in our seismic network. The thickness map of S2 shows a distinct depot center at the center of the eastern delta area. A closer look onto S2, however, reveals that the current sediment thickness does not represent the initial sequence thickness (Fig. 8b). With a closer look at profile issyk019, it 

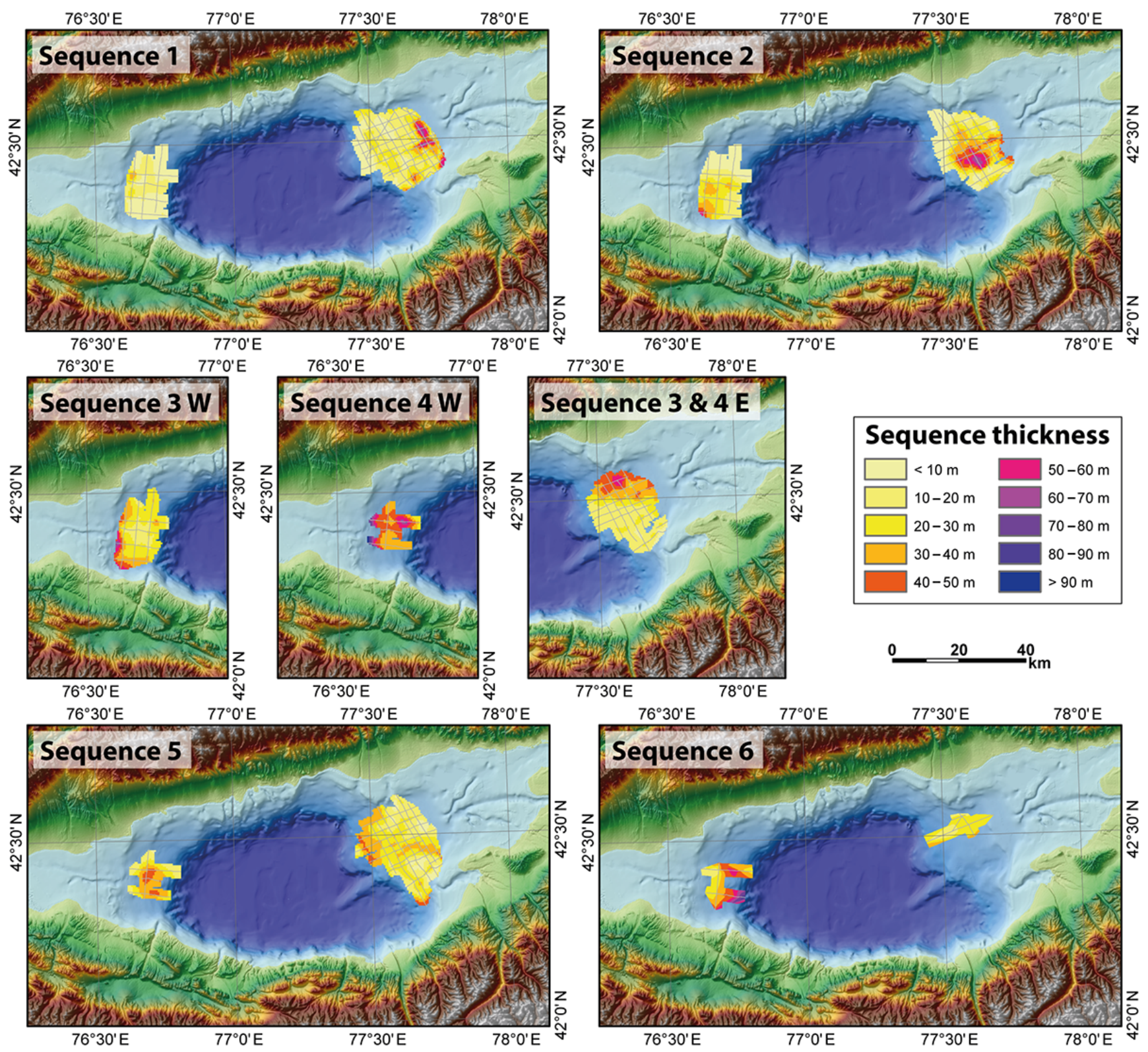

Figure 7. Minimum thickness of sequences in the western and eastern areas. Thickness is converted from two-way travel time using a seismic velocity of $1500 \mathrm{~m} \mathrm{~s}^{-1}$. Thickness color scale is similar for all panels and shown in the figure. Color scales for topography and bathymetry are similar to Fig. 1. Grey lines show where data were available for thickness calculation. Note that sequences 3 and 4 could only be distinguished in the western delta, while a combined thickness for sequences $3 \& 4$ was calculated for the eastern delta.

becomes obvious that large parts of both delta 2.2 and delta 2.1 were eroded. Where delta 2.1 was initially deposited, a river deeply incised the sediments, making this originally thick part of the sequence the thinnest at present. A second, more elongate, moderately thick depot center in the more proximal part could be a paleoriver channel that was incised into S3. It is located at the prolongation of the current Djyrgalan sub-lacustrine channel and must have formed during a time span with lower than present lake level.
S1 could be identified in seismic profiles in both the eastern and western delta areas (Figs. 5 and 6). It contains the uppermost, youngest sediments and its upper boundary forms the current lake floor. It lies above an erosional unconformity with channels deeply incised (up to $35 \mathrm{~m}$ ) into S2 at several spots (Fig. 8a). Sediments of S1 fill these channels, which is clearly visible in sediment thickness (Fig. 7). In its distal part, it drapes the underlying topography with a shelf break at ca. $340 \mathrm{~m}$ and prodeltaic sediments of SF2 deeper down. The lower- 
Table 1. Water depth below current lake level for each identified delta. Profiles issyk0049, ik30, and ik28 are located on the western delta and all other profiles are located on the eastern delta. Two-way travel time was converted to water depth using a sound velocity of $1500 \mathrm{~m} \mathrm{~s}^{-1}$. Mean = average value. $\mathrm{SD}=$ standard deviation calculated for each delta lobe including measurements from the eastern and western areas where available.

\begin{tabular}{|c|c|c|c|c|c|c|c|c|c|c|c|c|}
\hline \multirow[b]{2}{*}{ Lobe no. } & \multicolumn{3}{|c|}{ Western delta } & \multicolumn{7}{|c|}{ Eastern delta } & \multicolumn{2}{|c|}{ Combined } \\
\hline & issyk049 & $\mathrm{ik} 30$ & $\mathrm{ik} 28$ & issyk017 & issyk019 & issyk021 & $\mathrm{ik} 49$ & issyk022 & issyk024 & $\mathrm{ik} 07$ & Mean & SD \\
\hline 1.7 & & & & & & & & & 29 & 26 & 27.5 & 2.1 \\
\hline 1.6 & 161 & 155 & 155 & 154 & 151 & 147 & 154 & 153 & 149 & 154 & 153.3 & 3.8 \\
\hline 1.5 & & & & & & 199 & 203 & & & & 201.0 & 2.8 \\
\hline 1.4 & & 228 & & & & 228 & & & & & 228.0 & 0.0 \\
\hline 1.3 & 252 & 246 & & & & 250 & 254 & 254 & & & 251.2 & 3.3 \\
\hline 1.2 & & & & & & 263 & & & & & 263.0 & - \\
\hline 1.1 & & & & 294 & 279 & 283 & & & & & 285.3 & 7.8 \\
\hline 2.2 & 244 & & 244 & 252 & 248 & 261 & & & & & 249.8 & 7.1 \\
\hline 2.1 & & 206 & & 215 & 203 & 217 & & & & & 210.3 & 6.8 \\
\hline 3.2 & 174 & 180 & 162 & & & & & & & & 172.0 & 9.2 \\
\hline 3.1 & & & 330 & & & & & & & & 330.0 & - \\
\hline 4.3 & 399 & 395 & & & & & & & & & 397.0 & 2.8 \\
\hline 4.2 & 252 & 255 & 251 & & & 241 & & & & & 249.8 & 6.1 \\
\hline 4.1 & 315 & 327 & 314 & & & & & & & & 318.7 & 7.2 \\
\hline 5.2 & 366 & 373 & 379 & 359 & 358 & 350 & & & & & 364.2 & 10.6 \\
\hline 5.1 & 280 & 274 & & 283 & 295 & 286 & & & & & 283.6 & 7.8 \\
\hline 6.2 & 386 & 371 & 370 & 335 & 344 & 360 & & & & & 361.0 & 18.8 \\
\hline 6.1 & 474 & 448 & & & & & & & & & 461.0 & 18.4 \\
\hline 7.5 & 504 & & & & & & & & & & 504.0 & - \\
\hline 7.4 & 471 & 448 & 444 & & & & & & & & 454.3 & 14.6 \\
\hline 7.3 & 424 & 411 & 410 & 406 & 405 & 417 & & & & & 412.2 & 7.2 \\
\hline 7.2 & & & & 384 & 381 & 378 & & & & & 381.0 & 3.0 \\
\hline 7.1 & 326 & 320 & 335 & 330 & 328 & 342 & & & & & 330.2 & 7.6 \\
\hline
\end{tabular}

most part of S1 forms a small delta lobe (1.1) at approximately $285 \mathrm{~m}$ b.l.1. This lobe is overlain by a succession of transgressional units of SF3 (Fig. 8a). On some profiles, a series of smaller delta lobes (1.2 to 1.5$)$ is visible at water depths of 263, 251, 228, and $201 \mathrm{mb}$ b.1.1. (Table 1). A distinct large delta lobe (1.6) is visible in almost all profiles at a water depth of ca. $153 \mathrm{mb}$ b.l.1. Only in profiles issyk024 and ik07, which reach into the shallowest parts of the lake on the eastern delta area, could the uppermost and currently active delta lobe (1.7) at $28 \mathrm{~m}$ b.l.1. be identified. The distal prodeltaic sediments associated with delta lobe 1.7 , however, can be identified as thin drape on almost all profiles of both the eastern and western delta areas (Fig. 8a). The lake-floor morphology shows a shelf break at approximately $150 \mathrm{mb}$ b.1.1. The large shallow areas above the present-day delta at ca. $30 \mathrm{mb}$ b.l.1. are characterized by subaquatic channels that begin at the mouths of the large rivers at the eastern shore and in front of the paleo-channel of the Chu River at the western shore. These channels can be followed over the entirety of the plateaus and end at approximately $110 \mathrm{mb}$.1.1. S1 can be interpreted as starting with a relative lake-level lowstand during the formation of its lowermost delta 1.1.
During this lake-level lowstand, erosion took place in the hinterland and likely formed the river incisions that are visible at the boundary between $\mathrm{S} 1$ and $\mathrm{S} 2$ in profile issyk019 (Fig. 8a) and in nearby profiles. The lakelevel lowstand was followed by a rapid transgressional phase ending with a slightly slower lake-level rise from 263 to $201 \mathrm{~m}$ b.l.1. The sedimentary infill of the deeper channel was likely deposited during this transgressional phase. A second lake-level stillstand took place during the formation of the delta 1.6, followed by the current situation in which delta 1.7 is being deposited approximately $28 \mathrm{~m}$ b.1.1.

\section{Discussion}

\subsection{Tectonic origin of the lake}

Most of the 84 sparker profiles used in this study are located either in the eastern or western shallow parts of the lake (Fig. 1). While they image the delta areas in great detail, they do not provide much information on the tectonic origin of the lake. Profile ik01 crosses the lake in $\mathrm{N}-\mathrm{S}$ direction and here the tectonic nature of the lake becomes obvious: sediments dip towards the south, pointing to higher subsidence rates in 

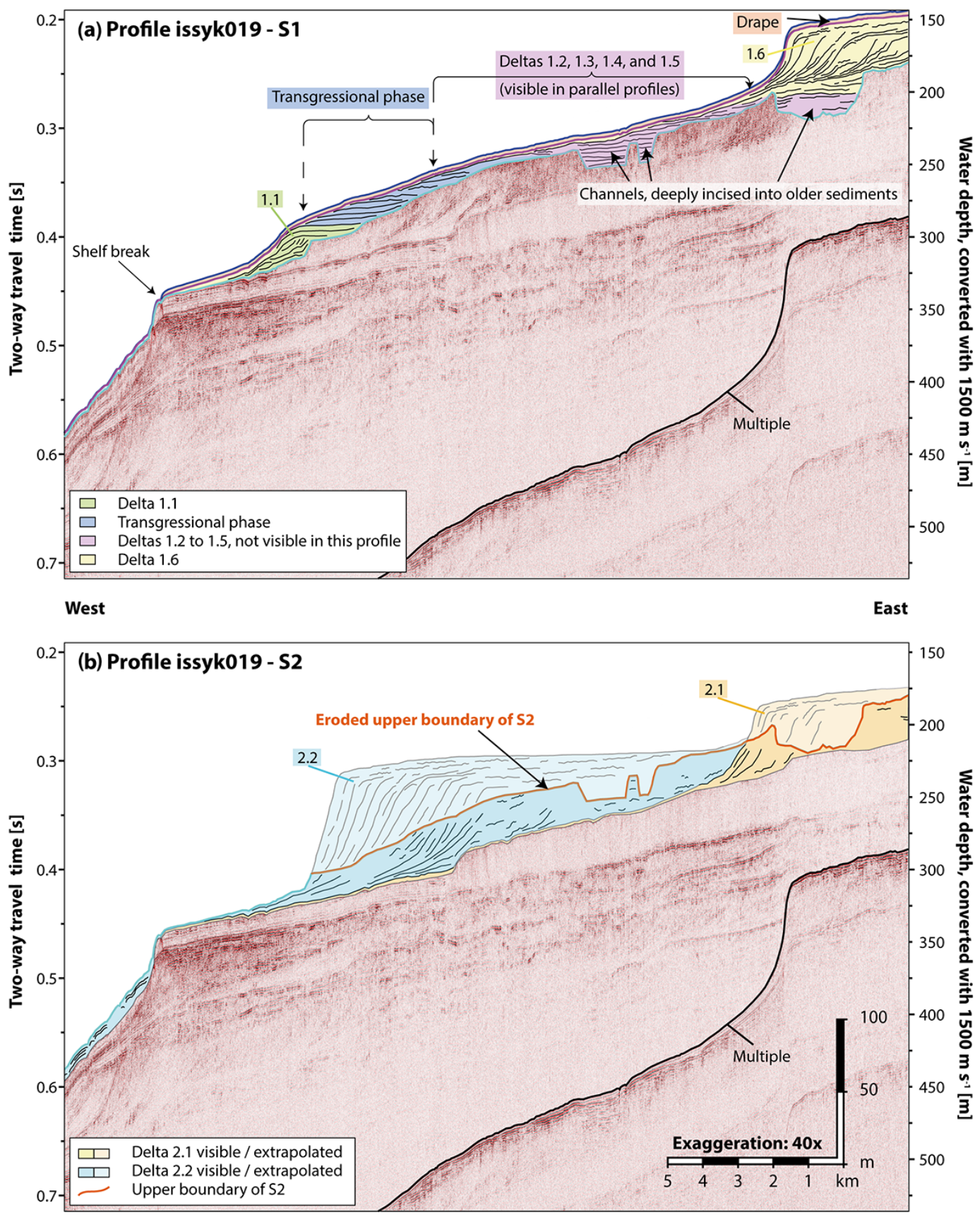

Figure 8. Sequences 1 and 2 on seismic profile issyk019. Upper panel: sequence 1 with distinct deltas 1.1 and 1.6 and the transgressional phase. Deltas 1.2 to 1.5 are only visible in parallel profiles, but their relative location is marked. Note that the lower boundary of Sequence 1 is highly erosive with deeply incised channels. Lower panel: sequence 2 . The missing (eroded) parts of deltas 2.1 and 2.2 are tentatively completed in light colors for better visualization. Seismic data overlaying the respective sequences are removed.

that region (Fig. 4). This is visible to at least $200 \mathrm{~m}$ below the lake floor. Within the imaged lake profiles, the faults responsible for the asymmetry of the basin are not visible, but studies along the southern margin of the lake document the presence of a series of faults roughly parallel to the long axis of the lake (e.g., Burgette, 2008; Macaulay et al., 2014, 2015). The north-vergent main Terskey Fault (MTF) is the most im- portant basin-bounding fault, with over $8 \mathrm{~km}$ of structural relief with respect to the lake (Macaulay et al., 2013; Fig. 1). Apatite fission-track studies show that this structure became active in the latest Oligocene to early Miocene. In seismic profile ik01, the dip angle of the strata seems to change quite continuously over time with no sign of an abrupt change, and the deformation still seems to be active. This points to an on- 
going process. Short cores retrieved from the northern slope reveal that the sediment consists of a mixture of a terrigenous fraction (ranging from coarse sands to silty clays and clays) and a lacustrine, micritic carbonate fraction. Reported sedimentation rates vary between $0.47-0.56 \mathrm{~mm} \mathrm{yr}^{-1}$ (Ricketts et al., 2001), 0.49-0.59 $\mathrm{mm} \mathrm{yr}^{-1}$ (Giralt et al., 2004), and 0.23-0.39 $\mathrm{mm} \mathrm{yr}^{-1}$ (Larrasoaña et al., 2011; Gómez-Paccard et al., 2012) for the Holocene, based on ${ }^{14} \mathrm{C}$ and nuclide dating. Using a mean value of $0.45 \mathrm{~mm} \mathrm{yr}^{-1}$, this points to a minimum age of ca. $830 \mathrm{ka}$ for the lowermost sediment layers visible in the profiles. It is quite likely that the lake is significantly older because the acoustic basement was not detected in any of the profiles and because compaction of deeply buried sediments would additionally reduce apparent sedimentation rates. Deep bore holes and outcrops within the basin adjacent to the lake reveal up to $5 \mathrm{~km}$ of Cenozoic strata (Knauf, 1965; Turchinskiy, 1970; Fortuna, 1983); the older lacustrine record is poorly studied. Sedimentation rates used here are derived from cores located proximal to the northern shore, and sedimentation rates might be significantly lower in the central part of the lake. Additionally, large differences in sedimentation rates between glacials and interglacials are to be expected.

\subsection{Lake-level curve and age information}

Combining all information on lake-level stillstands, delta formation, regressional and erosional phases, a lake-level curve for Lake Issyk-Kul was established (Fig. 9). It comprises four phases of lake-level regression (in S7, S5, second part of S4, and S2) and four phases of lake-level transgression (S6, first part of S4, S3, and S1). The transition between the different sequences and thus the transition between regression and transgression cannot be clearly described due to the fact that the boundaries are mostly of erosive nature, mainly in the shallower parts of the lake. This is easily explained by the observation that the shallower parts of the sequences were subaerially exposed during the formation of lowstand deltas and thus were subject to erosion.

The lake-level curve in its present form only comprises the deltas/terraces that were formed inside the current lake; subaerially exposed terraces are not imaged in the seismic data, and their distal counterparts, i.e., the distal well-layered prodelta sediments, are not likely to be identified because they lie concordantly on the underlying sediment.

Different authors describe a series of terraces that are, today, subaerially exposed. The uppermost terrace in the lake area is located at $1675-1680 \mathrm{~m}$ above sea level (a.s.l.; Trofimov, 1990), which is some $70 \mathrm{~m}$ above the present-day lake level. Bowman et al. (2004) describe beach cliffs at an altitudinal range of 1620-1640 $\mathrm{m}$ a.s.l. These subaerially exposed terraces point to lake levels that were 70 and $13-33 \mathrm{~m}$ higher than present. Bowman et al. (2004) date these terraces to ages between $26.0 \pm 2.1 \mathrm{ka}$ for the upper ones and $10.5 \pm 0.7 \mathrm{ka}$ for the lower ones, which is in agreement with an older date of $26.34 \pm 0.54 \mathrm{ka}$ for an upper terrace (Markov, 1971). This means that the lake-level highstand at $33 \mathrm{~m}$ above the lake level occurred roughly at the beginning of Marine Isotope Stage (MIS) 2. Lake Issyk-Kul's lake surface today is almost at the spillover level. Terraces at 33 and $70 \mathrm{~m}$ higher than the current lake surface would mean that the outflow must have been dammed by a dam approximately 33 and $70 \mathrm{~m}$ higher than today for a substantial time so terraces could have formed. With the current topography, this scenario is rather unlikely, and the subaerial terraces might also just have been uplifted from their original position. On the other hand, young lacustrine sediments are interbedded with fluvial conglomerates in Boom Canyon (Fig. 1), suggesting that the narrow gorge was dammed in the past. This could have blocked the current lake's spillover point, maybe resulting in lake levels higher than would be possible today.

Sub-lacustrine channels are visibly incised into S1 (Fig. 1) on the large shallow parts of the eastern stacked-delta complexes. On the eastern complex, these are associated with the prolongation of the rivers that currently feed Lake Issyk-Kul. On the western complex, the paleo-channel marks the ancient position of where the Chu River entered the lake before it was redirected (De Batist et al., 2002). Today the Chu River flows approximately $10 \mathrm{~km}$ west of the lake. The channels were likely formed at a lake-level lowstand at $110 \mathrm{mb}$ b.l.1., which - taking into account the $30 \mathrm{~m}$ of water that are today measured on top of the currently active delta - corresponds to a delta depth of roughly $140 \mathrm{~m}$. The channel morphology is still very distinct, pointing to a rather young event during which they were formed, so it is quite likely that they eroded into the subaerially exposed sediments of S1 while delta 1.6 was formed at a water depth of $153 \mathrm{~m}$. Older Russian literature dates this lowstand as following the MIS2 regression marked by the subaerial terraces mentioned above (Markov, 1971; Bondarev and Sevastyanov, 1991). This would imply that delta 1.6 was deposited after a significant lake-level fall of more than $100 \mathrm{~m}$. Seismic data, however, show a succession of a delta (1.1) at a water depth of $285 \mathrm{~m}$ b.l.1., a transgressional phase followed by a stepwise increase with smallscale deltas (1.2 to 1.5 ) at water depths of $263,251,228$, and $201 \mathrm{~m}$ b.1.1. before the formation of delta 1.6 at $153 \mathrm{~m}$ b.1.1., with no sign of a lake-level highstand in between. It is thus unlikely that the lake level was high before the formation of delta 1.6, providing evidence that the subaerially exposed lake terraces might not be located in their original position but significantly uplifted.

\subsection{Lake-level variations and their trigger mechanisms}

Lake-level variations are always a sign of changes in the hydrological regime of a lake. Basically, two different mechanisms can affect the hydrological regime: (i) a change in lake geometry, e.g., (differential) subsidence, a blocking of the outlet stream or, contrarily, the formation of a new outlet 


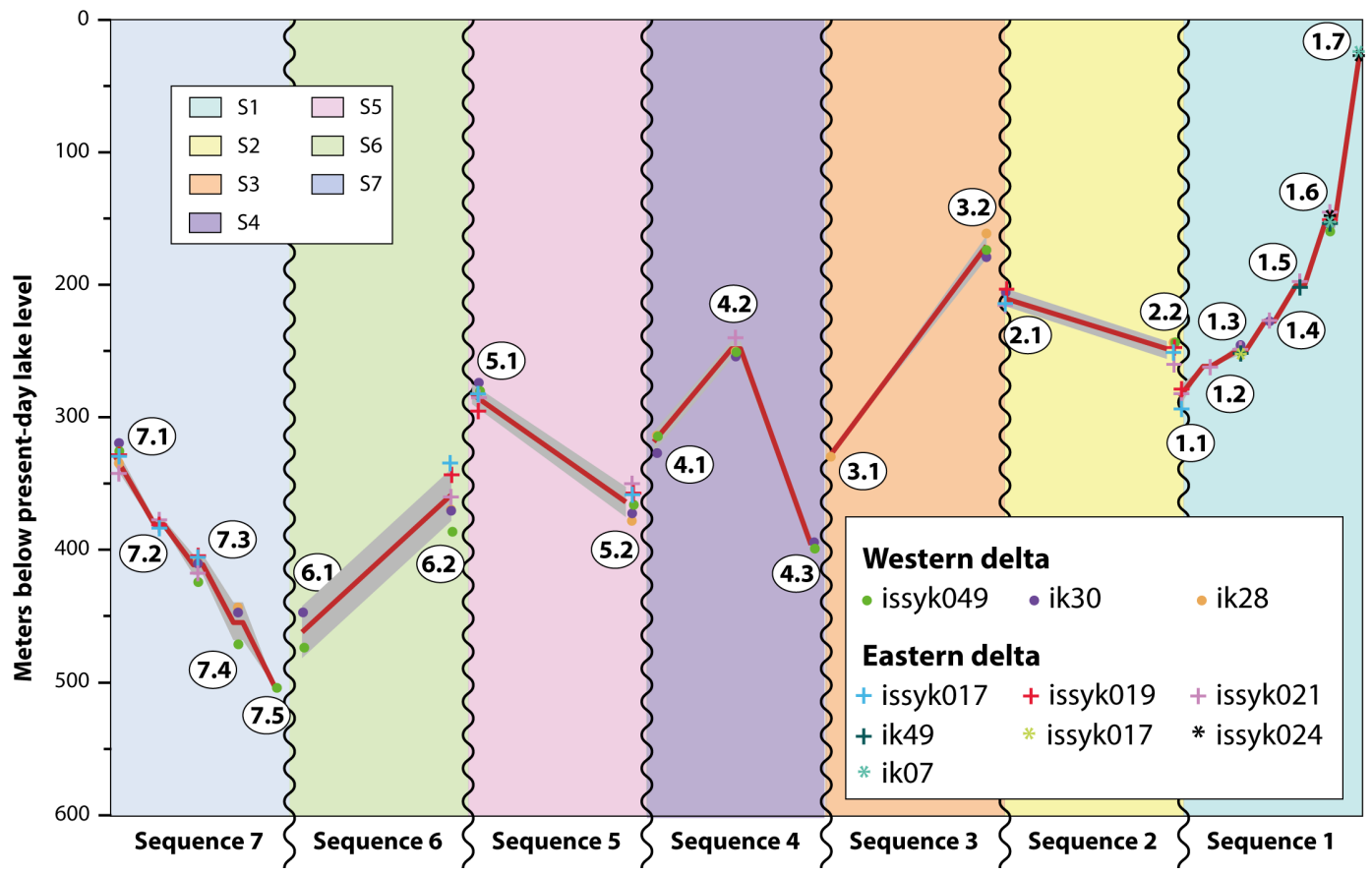

Figure 9. Lake-level curve of Lake Issyk-Kul. Red line: mean value of delta depths. Gray shading: standard deviation of delta depths. Numbers correspond to delta numbers in the text and in Table 1. Boundaries in between the different sequences are at least partially erosive.

and (ii) a change in the balance between precipitation/inflow and evaporation/outflow.

\subsection{Changes in lake geometry}

Lake Issyk-Kul is located in a tectonically, highly active area, which at first glance makes it likely that lake-level changes may have their primary origin in tectonic events. The lake basin is located in the intramontane Issyk-Kul Basin that is separated from the surrounding mountain ranges (the Kungei Alatau towards north and the Terskei Alatau towards south, Fig. 1) by fault zones. Most of the late Cenozoic strain has been accommodated by the adjacent mountain ranges, and as a result, the Issyk-Kul Basin and the lake basin in its center have been mostly protected from strong deformation (Abdrakhmatov et al., 2002). This is confirmed by the mostly well-layered sediments observed in the lake; however, evidence for tectonic influence is present (e.g., the tilting of the central basin deposits towards the south, and the occurrence of mass transport deposits likely caused by underwater slope destabilization due to seismic shaking).

Lake-level changes could be linked to tectonically driven subsidence or exhumation that would (a) either influence the entire lake, (b) parts of it, or (c) the inlets and/or outlets:

(a) From the well-layered sediments in the central part of the lake it is quite obvious that the general sedimentation pattern did not change significantly during the time interval which we can observe. The strata are al- most perfectly horizontal in W-E direction, but dip gently towards south with dip angles increasing with depth. This points to differential subsidence only between the northern and the southern part of the lake, and the subsidence seems to have been relatively constant through time. In order to generate such a highly dynamic lakelevel curve as for Lake Issyk-Kul (Fig. 9) with several cycles of increases and decreases and a total difference of at least $400 \mathrm{~m}$, it is virtually impossible that the lakelevel variations were generated by fault-driven uplift or subsidence within the lake. A general trend is nonetheless probable and confirmed by the differential subsidence between the northern and southern shore imaged in the sediments, but superimposed by another mechanism that is responsible for the dynamic change in lake level.

(b) Delta depths for almost all delta lobes are almost identical on both the eastern and western delta, hence it is unlikely that these two areas experienced significantly different histories. Even though some delta lobes were only identified in one delta, many other lobes are observed at identical depths on both deltas. In the case of S7, lobe 7.1 was observed at $327 \mathrm{mb}$.1.1. in the west and $333 \mathrm{mb}$ b.1.1. in the east, lobe 7.2 is missing in the west, 7.3 was observed at $415 \mathrm{mb}$ b.1.1. in the west and $409 \mathrm{~m}$ b.1.1. in the east, lobe 7.4 was found at $454 \mathrm{~m}$ and lobe 7.5 at $504 \mathrm{~m}$ b.1.1. in the west only. The differences between east and west are not larger than those between 
the lobe depths identified within one delta if identified in several profiles. Also, for example, lobe 7.5 was only identified in one profile in the western delta. It is therefore likely that those delta lobes that were only observed in one of the deltas are in fact not missing in the other but were just not identified in our study, either because our seismic profiles were not placed perfectly to image that specific lobe or maybe even because this lobe was eroded after its deposition.

(c) Tectonic events can also influence inlets and outlets of a lake, which in turn at least partly control lake level. At present, Lake Issyk-Kul is a closed system without any outlets but in the past the lake was drained through an outlet at its western end. The Chu River entered the lake in the southern and in the northern part of the western delta. At some point during the late Pleistocene, its course changed and it currently bypasses the lake and flows through Boom Canyon towards northwest due to a gentle topographic barrier between the river and the lake. This barrier was likely caused by changes in the tectonic settings (Bondarev and Sevastyanov, 1991). This means that Lake Issyk-Kul not only has no current outlet, but also no large inflow through the western delta. Should the Chu River keep its current course, this would result in a decline in sediment accumulation in the western delta, and delta lobes would likely not develop as pronounced in this part of the lake in the future. A lake-level rise of $13 \mathrm{~m}$, however, would flood the barrier and reactivate the Chu River as an outflow. At the beginning of the 19th century, Lake IssykKul drained through the Chu River for some 25 years (Merkel and Kulenbekov, 2012). The maximum documented lake level that Lake Issyk-Kul has experienced is at $1680 \mathrm{~m}$ a.s.l, i.e., $73 \mathrm{~m}$ above present lake level (Trofimov, 1990). With the current topography, it would not be possible to generate terraces at $73 \mathrm{~m}$ above lake level as the lake would overflow at $+13 \mathrm{~m}$. This suggests that during the period where water reached $73 \mathrm{~m}$ above lake level, either the current possible overflow channel - the Boom Canyon - was blocked; or the lake surroundings have been uplifted relative to the lake itself since that time and the $+73 \mathrm{~m}$ terraces were initially deposited at another - lower - altitude; or the entire lake basin and lake have been uplifted and all terraces are not at their original position. As the present structural setting would be predicted to raise the range with respect to the lake, the latter scenario seems unlikely. Grosswald et al. (1994) report that alpine glaciers have extended to the present shoreline and likely into the Chu River valley in the past, so they may have dammed the lake and facilitated lake levels higher than currently possible.

It is unlikely that the current bypassing of the Chu River is a common situation in the lake's history. In addition to the blocked outlet, this in fact also means that a large river entering from the west is missing. The pronounced delta lobes that formed contemporarily in the east and west point to sediment sources at both ends during at least the period that is spanned by sequences 7 to 1 .

All things considered, we propose that the lake-level fluctuations identified in our seismic data do not originate from tectonic activity only. Tectonic activity in this region might result in an overall trend of the lake level, but not in the highly dynamic, repeated cycles of rise and fall. These must have been the result of significant changes in precipitation and/or evaporation.

\subsubsection{Changes in precipitation/evaporation}

Today, climate and hence precipitation/evaporation in the Tien Shan is mainly controlled by the interaction between the midlatitude Westerlies and the Siberian High (e.g., Aizen et al., 1997; Zech, 2012). The midlatitude Westerlies bring moisture from the Aral-Caspian Basin, the Mediterranean, the Black Sea and the North Atlantic (Aizen et al., 2006; Lauterbach et al., 2014), while the Asian summer monsoon has only been of minor importance, at least since the midHolocene (Cheng et al., 2012). The Siberian High reaches south to the Tien Shan area and blocks the midlatitude Westerlies during winter, which results in low winter precipitation due to the dry air masses of the Siberian High (Aizen et al., 1995, 2001; Ricketts et al., 2001). Maximum precipitation is observed in spring and summer, and additionally in fall in areas with altitudes of less than $3000 \mathrm{~m}$ (Aizen et al., 2001). Between 1931 and 1990, precipitation has increased significantly in the northern Tien Shan by up to $108 \mathrm{~mm}$ (Aizen et al., 2001). Aizen et al. (2001) interpret this increase as a stronger influence of the midlatitude Westerlies on precipitation, which might result from an increase in global air temperature and a weakening or displacement of the Siberian High. Lake level, however, has fallen by $3 \mathrm{~m}$ since 1926 (Ricketts et al., 2001), partly due to Soviet era hydrological projects, but also by increased evaporation due to increased temperature (Romanovsky, 1990, 2002; Ricketts et al., 2001).

Lake Issyk-Kul is currently mainly fed by riverine input, which in turn is mainly controlled by snow and glacier melt as well as by rainfall. Lake-level changes are therefore highly dependant on precipitation and evaporation, which in turn are controlled by moisture and air temperature. With lake-level changes of up to $400 \mathrm{~m}$, the lake's archive shows that the interplay between the Siberian High and midlatitude Westerlies has been highly dynamic during the past, and likely since the formation of the lake. Unfortunately, we do not have age information from the delta lobes. Even though some age and sediment accumulation information is available from short sediment cores mostly from the mid-slope area (e.g., Ricketts et al., 2001; Giralt et al., 2004), these data are not helpful in estimating ages of the different delta lobes. Delta systems 
are just too dynamic with large differences in accumulation rates depending on the proximity to the rivers and to their total sediment load (bedload and suspended load) to use generalized accumulation rates. Additionally, erosional contacts between the different sequences could be observed but the amount of missing sediment could not be quantified. Drilling of sediment cores from the different sediment lobes would be required in order to reliably date the lake-level stillstands. Lake Issyk-Kul with its long sedimentary archive therefore provides an ideal drill site to study the history of the interplay between the Siberian High, the midlatitude Westerlies and the Asian summer monsoon through time (Oberhänsli and Molnar, 2012). The lake is located in an area with high relief, implying different climate conditions over short distances. Nevertheless, lake-level changes of up to $400 \mathrm{~m}$ are significant and rather a result of large-scale changes in climate patterns rather than of regional differences.

In an arid area such as the Issyk-Kul region, glaciers are highly sensitive to changes in precipitation/evaporation. Evidence from glacial features such as moraines, however, is limited and does not reach further back in time than to MIS6 (e.g., Zech, 2012); in the Kyrgyz Tien Shan, existing ages only reach back to MIS5e (Koppes et al., 2008). Zech (2012) showed that the glaciation in the Tien Shan and the Pamir became successively more restricted from MIS4 to MIS2, which was also observed in Siberia with limited ice sheet and glacier extents (e.g., Svendsen et al., 2004; Zech et al., 2011). Zech (2012) interprets this as a result from reduced moisture advection through the midlatitude Westerlies due to the lee effect when flowing over the massive Fennoscandian Ice Sheet, and additionally by a blocking situation of the Westerlies by a strong Siberian High. Low lake level would likely be caused by low precipitation and, thus, points to a strong Siberian High. This would imply that sequences 7, 5, and 2 represent times of a strong Siberian High and weakened midlatitude Westerlies. Sequences 6, 3, and 1, in turn, would point to a displaced or weakened Siberian High, with enhanced moisture input from the midlatitude Westerlies and, possibly, also by the Asian summer monsoon. The extent of the past glaciations in the Arctic region was variable (e.g., Svendsen et al., 2004; Jakobsson et al., 2014), which makes it likely that the precipitation regime was also different. Glaciation in the Tien Shan might have been rather limited during arid glacials and lake level may have been low. During glacials with wetter conditions, glaciers may have reached the lake and may even have blocked the outlet, potentially leading to the highest lake levels recorded, higher than during (moist) interglacials without blocked outlets. It is therefore impossible to relate sequence boundaries to glacials or interglacials without direct dating of sedimentary material.

\section{Conclusions}

A seismic study of mainly the western and eastern delta of Lake Issyk-Kul exhibits seven stratigraphic sequences (S7 = oldest, $\mathrm{S} 1=$ youngest). Boundaries between the sequences are often erosive (erosional unconformities), and each stratigraphic sequence contains at least two delta lobes formed during times of relatively constant lake level. The topset-foreset rollover point was considered as a proxy for lake-level change. In this context, S7, S5, and S2 can be interpreted as formed during falling lake level, while S6, S3, and $\mathrm{S} 1$ indicate a lake-level rise. S4 exhibits a lake-level rise followed by a lake-level fall. Taking into account the subaerially exposed lake terraces, a total of at least $400 \mathrm{~m}$ of lake-level change could be observed.

While tectonic reasons may have had some influence on lake-level evolution, they were clearly not causal for the cyclic rise and fall. Changes in precipitation/evaporation are more likely, causing changes in water level. Currently, the dry air masses of the Siberian High are strong in winter, blocking the midlatitude Westerlies. During summer, the midlatitude Westerlies bring moist air into the area, resulting in precipitation peaks in spring/summer and fall. Lakelevel changes point to changes in the atmospheric circulation pattern during the past. Low lake levels point to less precipitation, likely with a strong and stable Siberian High, and high lake levels may have been caused by a weakened or displaced Siberian High and stronger midlatitude Westerlies, possibly even influenced by the Asian summer monsoon. Dating of the cyclic regression/transgression cycles would be fundamental for a better understanding of the regional climate. Drilling into the delta sediments would be needed to establish a chronostratigraphic framework.

\section{Data availability}

Seismic profiles are stored at the Renard Centre of Marine Geology, Universiteit Gent, Belgium, and can be obtained from Marc De Batist upon request (marc.debatist@UGent.be).

Acknowledgement. The seismic surveys were organized with support of the Belgian Science Policy Office (BELSPO) and the EU FP5 APELIK project. We would like to thank the captain and crew of RV Mфltur for the support during the seismic campaigns in 1997 and 2001. Comments by three anonymous reviewers significantly improved the quality of this manuscript.

The article processing charges for this open-access

publication were covered by a research

center of the Helmholtz Association.

Edited by: V. Rath

Reviewed by: three anonymous referees 


\section{References}

Abdrakhmatov, K. Y., Delvaux, D., and Djanuzakov, K. D.: Active tectonics and seismic hazard of the Issyk-Kul basin in the Kyrgyz Tian-Shan, in: Lake Issyk-Kul: Its Natural Environment, edited by: Klerkx, J. and Imanackunov, B., Kluwer Academic Publishers, Dordrecht, 101-123, 2002.

Aizen, E. M., Aizen, V. B., Melack, J. M., Nakamura, T., and Ohta, T.: Precipitation and atmospheric circulation patterns at midlatitudes of Asia, Int. J. Climatol., 21, 535-556, 2001.

Aizen, V. B., Aizen, E. M., and Melack, J. M.: Climate, snow cover, glaciers, and runoff in the Tien Shan, Central Asia, Water Resour. Bull., 31, 1113-1129, 1995.

Aizen, V. B., Aizen, E. M., Melack, J. M., and Dozier, J.: Climatic and hydrologic changes in the Tien Shan, Central Asia, J. Climate, 10, 1393-1404, 1997.

Aizen, V. B., Aizen, E. M., Joswiak, D. R., Fujita, K., Takeuchi, N., and Nikitin, S. A.: Climatic and atmospheric circulation pattern variability from ice-core isotope/geochemistry records (Altai, Tien Shan and Tibet), Ann. Glaciol., 43, 49-60, 2006.

Amante, C. and Eakins, B. W.: ETOPO1 1 Arc-Minute Global Relief Model: Procedures, Data Sources and Analysis, in: NOAA Technical Memorandum NESDIS NGDC-24, 19 pp., 2009.

Anselmetti, F. S., Ariztegui, D., Hodell, D. A., Hillesheim, M. B., Brenner, M., Gilli, A., McKenzie, J. A., and Mueller, A. D.: Late Quaternary climate-induced lake level variations in Lake Petén Itzá, Guatemala, inferred from seismic stratigraphic analysis, Palaeogeogr. Palaeocl., 230, 52-69, 2006.

Anselmetti, F. S., Ariztegui, D., De Batist, M., Gebhardt, A. C., Haberzettl, T., Niessen, F., Ohlendorf, C., and Zolitschka, B.: Environmental history of southern Patagonia unravelled by the seismic stratigraphy of Laguna Potrok Aike, Sedimentology, 56, 873-892, 2009.

Bartov, Y., Stein, M., Enzel, Y., Agnon, A., and Reches, Z. E.: Lake levels and sequence stratigraphy of Lake Lisan, the Late Pleistocene precursor of the Dead Sea, Quaternary Res., 57, 9-21, 2002.

Bondarev, L. G. and Sevastyanov, D. V.: Relief of shores and lake bottom, in: Leningrad, Nauka, Istoria ozer Sevan, IssykKul, Balkhash, Zaisan I Aral (The history of Sevan, Issyk-Kul, Balkhash, Zaisan and Aral Lakes), Leningrad, 78-86, 1991.

Bowman, D., Korjenkov, A., and Porat, N.: Late-Pleistocene seismites from Lake Issyk-Kul, the Tien Shan range, Kyrghyzstan, Sediment. Geol., 163, 211-228, 2004.

Burgette, R. J.: Uplift in response to tectonic convergence: The Kyrgyz Tien Shan and Cascadia subduction zone, Department of Geological Sciences, University of Oregon, USA, Oregon, USA, 262 pp., 2008.

Cheng, H., Zhang, P. Z., Spötl, C., Edwards, R. L., Cai, Y. J., Zhang, D. Z., Sang, W. C., Tan, M., and An, Z. S.: The climatic cyclicity in semiarid-arid central Asia over the past 500000 years, Geophys. Res. Lett., 39, 351-364, 2012.

Cukur, D., Krastel, S., Schmincke, H. U., Sumita, M., Tomonaga, Y., and Çağatay, M. N.: Water level changes in Lake Van, Turkey, during the past ca. $600 \mathrm{ka}$ : climatic, volcanic and tectonic controls, J. Paleolimnol., 52, 201-214, 2014.

De Batist, M., Imbo, Y., Vermeesch, P. M., Klerkx, J., Giralt, S., Delvaux, D., Lignier, V., Beck, C., Kalugin, I., and Abdrakhmatov, K. Y.: Bathymetry and sedimentary environments of
Lake Issyk-Kul, Kyrgyz Republic (Central Asia): a large, highaltitude, tectonic lake, edited by: Klerkx, J. and Imanackunov, B., Lake Issyk-Kul: Its Natural Environment, Kluwer Academic Publishers, Dordrecht, 101-123, 2002.

De Mol, L.: Reconstructie van meerspiegelschommelingen in het Issyk-Kul Meer (Kirgizie') op basis van de geomorfologische en seismostratigrafische analyse van rivierdelta's, Vakgroep Geologie en Bodemkunde, University of Gent, Gent, 2006.

Degens, E. T., Wong, H. K., Kempe, S., and Kurtman, F.: A geological study of Lake Van, Eastern Turkey, Geol. Rundsch., 73, 701-734, 1984.

Delvaux, D., Abdrakhmatov, K., and Strom, A. L.: Landslides and surface breaks of the 1911 Ms 8.2 Kemin earthquake, Kyrgyzstan, Russ. Geol. Geophys+, 42, 1165-1177, 2001.

Dutton, A., Carlson, A. E., Long, A. J., Milne, G. A., Clark, P. U., DeConto, R., Horton, B. P., Rahmstorf, S., and Raymo, M. E.: SEA-LEVEL RISE. Sea-level rise due to polar ice-sheet mass loss during past warm periods, Science, 349, aaa4019-1aaa4019-9 doi:10.1126/science.aaa4019, 2015.

Fleming, K., Johnston, P., Zwartz, D., Yokoyama, Y., Lambeck, K., and Chappell, J.: Refining the eustatic sea-level curve since the Last Glacial Maximum using far- and intermediate-field sites, Earth Planet. Sc. Lett., 163, 327-342, 1998.

Fortuna, A. B.: Spore and pollen complexes and stratigraphy of the Paleogene and Neogene sediments of the northern Tien Shan (in Russian), Institute of Seismology of the Academy of Sciences of the Kyrgyz SSR. Dushanbe, Tajikistan, Dushanbe, Tajikistan, 1983.

Gebhardt, A. C., Ohlendorf, C., Niessen, F., De Batist, M., Anselmetti, F. S., Ariztegui, D., Kliem, P., Wastegård, S., and Zolitschka, B.: Seismic evidence of up to $200 \mathrm{~m}$ lake-level change in Southern Patagonia since Marine Isotope Stage 4, Sedimentology, 59, 1087-1100, 2012.

Giralt, S., Riera, S., Leroy, S., Buchaca, T., Klerkx, J., De Batist, M., Beck, C., Bobrov, V., Catalan, J., Gavshin, V., Julia, R., Kalugin, I., Kipfer, R., Lignier, V., Lombardi, S., Matychenkov, V., Peters, F., Podsetchine, V., Romanovsky, V. V., Shukonikov, F., and Voltattorni, N.: 1000-years of environmental history of Lake Issyk- Kul, in: Dying and Dead Seas: Climatic Versus Anthropic Causes, edited by: Nihoul, J. C. J., Zavialov, P. O., and Micklin, P. P., Kluwer Academic Publishers, 253-285, 2004.

Gómez-Paccard, M., Larrasoaña, J. C., Giralt, S., and Roberts, A. P.: First paleomagnetic results of mid- to late Holocene sediments from Lake Issyk-Kul (Kyrgyzstan): Implications for paleosecular variation in central Asia, Geochem. Geosys., 13, Q03019, doi:10.1029/2011GC004015, 2012.

Goryachev, A. V.: Mesozoic-Cenozoic structure, history, tectonic development, and seismicity of the regions of Lake Issyk-Kul (in Russian), Moscow, 1959.

Grosswald, M. G., Kuhle, M., and Fastook, J. L.: Wurm glaciation of Lake Issyk-Kul area, Tien Shan Mts.: A case study in glacial history of Central Asia, Geojournal, 33, 1994.

Haq, B. U., Hardenbol, J., and Vail, P. R.: Chronology of fluctuating sea levels since the Triassic, Science, 235, 1156-1166, 1987.

Hodell, D. A., Anselmetti, F. S., Ariztegui, D., Brenner, M., Curtis, J. H., Gilli, A., Grzesik, D. A., Guilderson, T. J., Müller, A. D., Bush, M. B., Correa-Metrio, A., Escobar, J., and Kutterolf, S.: An 85-ka record of climate change in lowland Central America, Quaternary Sci. Rev., 27, 1152-1165, 2008. 
Imbo, Y.: Study of the evolution of the Issyk Kul basin (Tien Shan, Kyrgyzstan) based on high-resolution reflection seismics (Studie van de evolutie van het Issyk-Kul bekken (Tien Shan, Kirgizië) gebaseerd op hoge-resolutie reflectieseismische profielen), University of Ghent, Ghent, 1998.

Jakobsson, M., Andreassen, K., Bjarnadóttir, L. R., Dove, D., Dowdeswell, J. A., England, J. H., Funder, S., Hogan, K., Ingólfsson, Ó., Jennings, A., Krog Larsen, N., Kirchner, N., Landvik, J. Y., Mayer, L., Mikkelsen, N., Möller, P., Niessen, F., Nilsson, J., O'Regan, M., Polyak, L., Nørgaard-Pedersen, N., and Stein, R.: Arctic Ocean glacial history, Quaternary Sci. Rev., 92, 40-67, 2014.

Knauf, I.: Geological Map of the USSR of 1:200000 Scales, Northern Tien-Shan Series, Sheet K-44-XIII, Russian Geological Research Institute (VSEGEI), Nedra, Moscow, 1965.

Kodyaev, T. V.: Morfometrical characteristics of Issyk-Kul Lake, Izv. Vses. Geogr. Obshch., 105, 48-57, 1973.

Koppes, M., Gillespie, A. R., Burke, R. M., Thompson, S. C., and Stone, J.: Late Quaternary glaciation in the Kyrgyz Tien Shan, Quaternary Sci. Rev., 27, 846-866, 2008.

Korotaev, V. M.: Beregovaya zona ozero Issyk-Kul (Coastal zone of Lake Issyk-Kul), Frunze, 151, 1967.

Lambeck, K., Rouby, H., Purcell, A., Sun, Y., and Sambridge, M.: Sea level and global ice volumes from the Last Glacial Maximum to the Holocene, P. Natl. Acad. Sci. USA, 111, 15296-15303, 2014.

Larrasoaña, J. C., Gómez-Paccard, M., Giralt, S., and Roberts, A. P.: Rapid locking of tectonic magnetic fabrics in weakly deformed mudrocks, Tectonophysics, 507, 16-25, 2011.

Lauterbach, S., Witt, R., Plessen, B., Dulski, P., Prasad, S., Mingram, J., Gleixner, G., Hettler-Riedel, S., Stebich, M., Schnetger, B., Schwalb, A., and Schwarz, A.: Climatic imprint of the midlatitude Westerlies in the Central Tian Shan of Kyrgyzstan and teleconnections to North Atlantic climate variability during the last 6000 years, Holocene, 24, 970-984, 2014.

Lezzar, K. E., Tiercelin, J. J., De Batist, M., Cohen, A., Bandora, T., Van Rensbergen, P., Mifundu, W., and Klerkx, J.: New seismic stratigraphy and Late Tertiary history of the North Tanganyika Basin, East African Rift system, deduced from multifold reflection and high-resolution data and piston core evidence, Basin Res., 8, 1-28, 1996.

Litt, T., Krastel, S., Sturm, M., Kipfer, R., Örcen, S., Heumann, G., Franz, S. O., Ülgen, U. B., and Niessen, F.: "PALEOVAN", International Continental Scientific Drilling Program (ICDP): site survey results and perspectives, Quaternary Sci. Rev., 28, 15551567, 2009.

Lyons, R. P., Scholz, C. A., Cohen, A. S., King, J. W., Brown, E. T., Ivory, S. J., Johnson, T. C., Deino, A. L., Reinthal, P. N., McGlue, M. M., and Blome, M. W.: Continuous 1.3-million-year record of East African hydroclimate, and implications for patterns of evolution and biodiversity, P. Natl. Acad. Sci. USA, 112, 1556815573, 2015.

Macaulay, E. A., Sobel, E. R., Mikolaichuk, A., Landgraf, A., Kohn, B., and Stuart, F.: Thermochronologic insight into late Cenozoic deformation in the basement-cored Terskey Range, Kyrgyz Tien Shan, Tectonics, 32, 487-500, 2013.

Macaulay, E. A., Sobel, E. R., Mikolaichuk, A., Kohn, B., and Stuart, F. M.: Cenozoic deformation and exhumation history of the Central Kyrgyz Tien Shan, Tectonics, 33, 135-165, 2014.
Macaulay, E. A., Sobel, E. R., Mikolaichuk, A., Wack, M., Gilder, S. A., Mulch, A., Fortuna, A. B., Hynek, S., and Apayarov, F.: The sedimentary record of the Issyk Kul basin, Kyrgyzstan: climatic and tectonic inferences, Basin Res., 28, 57-80, doi:10.1111/bre.12098, 2016.

Machlus, M., Enzel, Y., Goldstein, S. L., Marco, S., and Stein, M.: Reconstructing low levels of Lake Lisan by correlating fan-delta and lacustrine deposits, Quatern. Int., 73-74, 137-144, 2000.

Markov, K. K.: Razrez noveishikh otlozhenii Issyk-Kulgskoi vpadiny (Sequence of the latest deposits of the Issyk-Kul basin), Moscow University Publishing House, Moscow, 1971.

Merkel, B. J. and Kulenbekov, Z.: Investigation of the natural uranium content in the Issyk-Kul Lake, Kyrgyzstan, Freiberg Online Geology 33, 3-45, 2012.

Moernaut, J., Verschuren, D., Charlet, F., Kristen, I., Fagot, M., and De Batist, M.: The seismic-stratigraphic record of lake-level fluctuations in Lake Challa: Hydrological stability and change in equatorial East Africa over the last $140 \mathrm{kyr}$, Earth Planet. Sc. Lett., 290, 214-223, 2010.

Molnar, P. and Tapponier, P.: Cenozoic tectonics of Asia: effects of a continental collision, Science, 189, 419-426, 1975.

Naudts, L.: Seismisch-stratigrafische interpretatie van een complex deltasysteem in het Issyk-Kul Meer, Kyrghyzstan, Vakgroep Geologie en Bodemkunde, University of Gent, Gent, 133 pp., 2002.

Oberhänsli, H. and Molnar, P.: Climate Evolution in Central Asia during the Past Few Million Years: A Case Study from Issyk Kul, Sci. Dril., 13, 51-57, doi:10.2204/iodp.sd.13.09.2011, 2012.

Ricketts, R. D., Johnson, T. C., Brown, E. T., Rasmussen, K. A., and Romanovsky, V. V.: The Holocene paleolimnology of Lake Issyk-Kul, Kyrgyzstan: trace element and stable isotope composition of ostracodes, Palaeogeogr. Palaeocl., 176, 207-227, 2001.

Romanovsky, V. V.: The Natural Complex of Lake Issyk-Kul, Academy Nauk Kyrgyzstan (in Russian), Frunze Ilim, 1990.

Romanovsky, V. V.: Water level variations and water balance of Lake Issyk-Kul, in: Lake Issyk-Kul: Its Natural Environment, edited by: Klerkx, J. and Imanackunov, B., Kluwer Academic Publishers, Dordecht, 45-57, 2002.

Scholz, C. A.: East African megadroughts between 135 and 75 thousand years ago and bearing on early-modern human origins, P. Natl. Acad. Sci. USA, 104, 16416-16421, 2007.

Scholz, C. A., Karp, T., Brooks, K. M., Milkereit, B., Amoako, P. Y. O., and Arko, J. A.: Pronounced central uplift identified in the Bosumtwi impact structure, Ghana, using multichannel seismic reflection data, Geology, 30, 939-942, 2002.

Schramm, A., Stein, M., and Goldstein, S. L.: Calibration of the ${ }^{14} \mathrm{C}$ time scale to $50 \mathrm{kyr}$ by ${ }^{234} \mathrm{U} /{ }^{230} \mathrm{Th}$ dating of sediments from Lake Lisan (the paleo-Dead Sea), Earth Planet. Sc. Lett., 175, 27-40, 2000.

Shanahan, T. M., Overpeck, J. T., Wheeler, C. W., Beck, J. W., Pigati, J. S., Talbot, M. R., Scholz, C. A., Peck, J., and King, J. W.: Paleoclimatic variations in West Africa from a record of late Pleistocene and Holocene lake level stands of Lake Bosumtwi, Ghana, Palaeogeogr. Palaeocl., 242, 287-302, 2006.

Stavinsky, S., Romanovski, V., Tarasov, S., Imankulov, B., Zepker, I., Meskheteli, A., and Kuznetsov, D.: Results of complex profiling of Lake Issyk-Kul, Unpubl. Report, Ministry of Geology, Bishkek, 1984.

Stockhecke, M., Sturm, M., Brunner, I., Schmincke, H.-U., Sumita, M., Kipfer, R., Cukur, D., Kwiecien, O., Anselmetti, F. S., and 
Ariztegui, D.: Sedimentary evolution and environmental history of Lake Van (Turkey) over the past 600000 years, Sedimentology, 61, 1830-1861, 2014.

Svendsen, J. I., Alexanderson, H., Astakhov, V. I., Demidov, I., Dowdeswell, J. A., Funder, S., Gataullin, V., Henriksen, M., Hjort, C., Houmark-Nielsen, M., Hubberten, H. W., Ingólfsson, Ó., Jakobsson, M., Kjær, K. H., Larsen, E., Lokrantz, H., Lunkka, J. P., Lyså, A., Mangerud, J., Matiouchkov, A., Murray, A., Möller, P., Niessen, F., Nikolskaya, O., Polyak, L., Saarnisto, M., Siegert, C., Siegert, M. J., Spielhagen, R. F., and Stein, R.: Late Quaternary ice sheet history of northern Eurasia, Quaternary Sci. Rev., 23, 1229-1271, 2004.

Trofimov, A. K.: Quaternary deposits of Issyk-Kul Basin in connection to its tectonics, Izvestia A.S. Kirghyzkoy SSR N1, 1990.

Turchinskiy, V. P.: Geological map of the USSR of 1:200 000 scales, Northern Tien Shan series, Sheet K-43-XVIII, Russ. Geol. Res. Inst., Nedra, Moscow, 1970.

Vail, P. R., Todd, R. G., and Sangree, J. B.: Seismic stratigraphy and global changes of sea level, Part five: chronostratigraphic significance of seismic reflections, Seismic Stratigraphy - Applications to Hydrocarbon Exploration, edited by: Payton, C. E., American Association of Petroleum Geologists Memoir 26, Tulsa, OK, 99 $116,1977$.
Vermeesch, P., Poort, J., Duchkov, A. D., Klerkx, J., and De Batist, M.: Lake Issyk Kul' (Tien Shan): Unusually low heat flow in an active intermontane Basin, Russ. Geol. Geophys., 45, 616-625, 2004.

Wack, M. R., Gilder, S. A., Macaulay, E. A., Sobel, E. R., Charreau, J., and Mikolaichuk, A.: Cenozoic magnetostratigraphy and magnetic properties of the southern Issyk-Kul basin, Kyrgyzstan, Tectonophysics, 629, 14-26, 2014.

Zabirov, R. D.: Location and morphology of the Lake, Ozero IssykKul (Lake Issyk-Kul), Frunze, 12-20, 1978.

Zech, R.: A late Pleistocene glacial chronology from the KitschiKurumdu Valley, Tien Shan (Kyrgyzstan), based on ${ }^{10}$ Be surface exposure dating, Quaternary Res., 77, 281-288, 2012.

Zech, W., Zech, R., Zech, M., Leiber, K., Dippold, M., Frechen, M., Bussert, R., and Andreev, A. A.: Obliquity forcing of Quaternary glaciation and environmental changes in NE Siberia, Quatern. Int., 234, 133-145, 2011. 